\title{
HABITAR NAS 'BUFFER ZONES' \\ DIRETRIZES ECO-SOCIAIS PARA UMA ARQUITETURA \\ INTEGRADA À INFRAESTRUTURA VERDE
}

DWELLING IN 'BUFFER ZONES'

ECO-SOCIAL GUIDELINES FOR AN ARCHITECTURE

INTEGRATED TO GREEN INFRASTRUCTURE

\begin{abstract}
José OtÁvio Lotufo
Arquiteto e urbanista pela Faculdade de Belas Artes da São Paulo (1996), mestre na área de Projeto Arquitetônico pela FAU-USP (2011), doutor na área de Projeto Arquitetônico pela FAU-USP (2016),

e-mail: zkltf@uol.com.br
\end{abstract}

\begin{abstract}
RESUMO
A pesquisa em Infraestrutura Verde se dá principalmente através do projeto da paisagem e da reconstituição da floresta urbana. Esta ênfase importante orienta transformações para o enfrentamento dos atuais desafios ambientais. Neste esforço conceitual e prático, surge uma questão de suma importância. Como o projeto arquitetônico, concomitante ao cumprimento de suas funções sociais, pode contribuir com os serviços ecossistêmicos prestados pela Infraestrutura Verde? O edifício, frequentemente um obstáculo aos processos ecossistêmicos, obstrui ou condiciona seus fluxos por desenhos distantes de uma abordagem ecológica. Ao propor o projeto da arquitetura como fator de contribuição à resiliência ecológica urbana, nós propomos diluir as fronteiras entre construção e paisagem, integrando o edifício à infraestrutura verde e redefinindo suas funções para além do programa arquitetônico tradicional.
\end{abstract}

Palavras-chave: Arquitetura; Urbanismo; Projeto sustentável; Resiliência ecológica urbana

\begin{abstract}
The Green Infrastructure research occurs mainly through the landscape design and the reconstitution of the urban forest. This important emphasis guides changes to face the current environmental challenges. In this conceptual and practical effort, an extremely important issue arises: how can the architectural project, together with the fulfillment of its social functions, contribute to the ecosystem services provided by the Green In-
\end{abstract}


frastructure? The building, usually an obstacle to ecosystemic processes, obstructs or conditions its flows through designs in conflict with an ecological approach. By proposing the architectural design as a factor of contribution to urban ecological resilience, it is suggested to dilute the border lines between construction and landscape, integrating the building with the green infrastructure and redefining its functions beyond the traditional architectural program.

Keywords: Architecture; Urbanism; Sustainable Design; Urban Ecological Resilience

“... por nossa saúde psíquica e bem-estar de nossas cidades, continuemos a encontrar maneiras de abrir espaço para a alma". [James Hillman]

\section{A natureza da cidade}

O conceito de Infraestrutura Verde veio para reafirmar a importância da natureza na cidade. Mais do que questões estéticas e de mitigação do impacto da urbanização, a natureza assume a função de prestadora de serviços socioecológicos. Quando valorados e devidamente contabilizados estes serviços demandam políticas de incentivo a projetos mais sustentáveis e menos imediatistas, investimentos em qualidade de vida com previsão de retornos a médio e longo prazo.

Mais frequentemente focadas no projeto da paisagem e na constituição da floresta urbana, as pesquisas em Infraestrutura Verde deixam em aberto uma lacuna importante que o presente trabalho se propõe a ocupar: o projeto arquitetônico. $O$ edifício é, em maior ou menor grau, um obstáculo aos processos ecossistêmicos. Quando projetado para maior resiliência ecológica urbana, contribui na dissolução destas barreiras, enquanto integramse construção e paisagem. Nosso objetivo é propor uma arquitetura que cumpra sua função social ao mesmo tempo que dê apoio e continuidade àquelas funções desempenhadas pela Infraestrutura Verde. Uma ética e estética alinhadas aos novos paradigmas.

Pensar o projeto da paisagem e o do edifício de forma isolada dificulta soluções integradas para os problemas abordados por cada um, criando conflitos e obstruções aos fluxos e funções por eles desempenhados. Para integrá-los se faz necessário adotar uma definição apropriada de ecossistema urbano. 
No que consiste um ecossistema urbano? Quando na década de 60 os irmãos Odum desenvolveram o conceito de ecossistema, a cidade começou a ser vista como uma máquina metabólica onde interagem componentes físicos e biológicos. Ainda só eram considerados o solo, a água, flora e fauna, enquanto que as construções e a vida nas comunidades humanas não eram levadas em conta. $O$ estudo se concentrava mais sobre os fragmentos de natureza na cidade, como os parques e áreas verdes. Um ecossistema urbano, no entanto, além dos elementos naturais, a saber, o meio físico (geologia, relevo e água) e biológico (fauna e flora), inclui elementos antrópicos, entendidos como construções (edifícios e infraestrutura), e a sociedade. Este conjunto se define como a "natureza da cidade" mais do que a "natureza na cidade" (PICKETT e CADENASSO, 2013) (fig.01). É a esse modelo que nos referimos neste trabalho como ecossistema urbano.

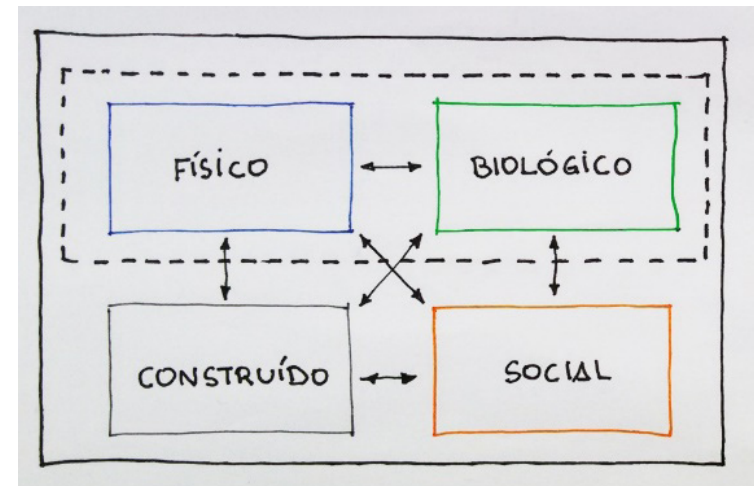

Figura 1 - Conceito de ecossistemas urbanos segundo Pickett e Cadenasso. Adaptação do autor. (LOTUFO, 2016)

\section{Resiliência ecológica urbana}

O conceito de resiliência se aperfeiçoou bastante desde sua concepção original pela física, adotada depois pela engenharia e aplicada nas primeiras gestões de ecossistemas. Por esta concepção inicial, um objeto era tomado de forma isolada em um estado de equilíbrio único. A resiliência referia-se à velocidade ou tempo de retorno ao seu estado original depois de sofrer uma deformação ou stress. Um exemplo simples é o do elástico. Há um ponto até onde ele pode ser deformado sem que sofra uma deformação definitiva ou ruptura. Este ponto, segundo esta definição, é o limite de resiliência. Quando este conceito foi aplicado à sistemas complexos, como os ecossistemas, a resiliência foi compreendida como a capacidade de retorno ao equilíbrio após sofrer um distúrbio. Pressupunha-se a existência de um estado único de equilíbrio para o qual deveria permanecer estável ou próximo da estabilidade, e um limite de resiliência 
que não poderia ser transposto. No entanto esta concepção começou a se mostrar deficiente (GUNDERSON et al., 2010).

Observava-se, no caso de ecossistemas, que a imposição de estabilidade causava diminuição de resiliência. Um exemplo clássico: o controle total de incêndios em uma floresta resulta em tal acumulação de matéria inflamável que qualquer faísca desencadeia um incêndio incontrolável. Quando este acúmulo não existe, os pequenos focos de incêndio não se alastram com tanta rapidez e colaboram em manter mais baixas as taxas de material inflamável, tornando a floresta menos propensa a incêndios de grande porte. As áreas atingidas por pequenos focos de incêndio recebem suporte natural de seus entornos não atingidos (GUNDERSON et al, 2010). O paradigma do "comando e controle" entra em crise e surge o da "gestão flexível".

Uma gestão eficiente deve reconhecer previamente quais atributos dão suporte à resiliência do ecossistema em questão. Uma vez que ecossistemas possuem diversos estados de equilíbrio, são naturalmente instáveis. A variabilidade e a imprevisibilidade são qualidades positivas. Não mais uma questão de estabilidade, a resiliência ecológica passa a ser compreendida como a medida de persistência de um sistema, ou seja, sua capacidade de absorver mudanças e perturbações enquanto mantém as funções e a constância das relações entre seus componentes (GUNDERSON et al, 2010).

Um gerenciamento ecológico eficiente é o que proporciona ao sistema maior capacidade adaptativa e imunológica, e oferece condições para um aperfeiçoamento constante. A dinâmica de sistemas ecológicos pôde ser melhor compreendida a partir dos conceitos de ciclos adaptativos e panarquia, como descritos por Gunderson e Holling (2002). Estes conceitos descrevem interações intra-escalares e inter-escalares, cuja dinâmica sustenta a resiliência de um sistema.

O modelo de ciclo adaptativo é descrito por quatro fases, a saber, (1) estruturação, (2) conservação, (3) desconstrução criativa e (4) reorganização. Relações de causa e efeito se estabelecem entre diversos ciclos adaptativos em diferentes escalas. Os ciclos em escalas maiores são geralmente mais lentos e em escalas menores mais rápidos. As relações de causa e efeito se dão em todas as direções. Quando de cima para baixo (top-down) recebem o nome de "recordação". Nas cidades isto se dá, por exemplo, na administração pública ou por políticas regidas por determinantes econômicas ou ideológicas. No sentido contrário (botton-up) recebem o nome de "revolta". Um exemplo de "revolta" na cidade é como um movimento de comunidade pode de- 
sencadear uma reestruturação política. Uma rede de ciclos adaptativos dentro de um ecossistema configura uma panarquia.

A panarquia descreve como variáveis em diversas escalas interagem determinando transformações em ecossistemas naturais ou sociais. Sugere interações top down e botton up, ou seja, que as transformações ecossistêmicas não estão submetidas a uma ordenação hierárquica clássica, ou exclusivamente de cima para baixo (fig. 02).
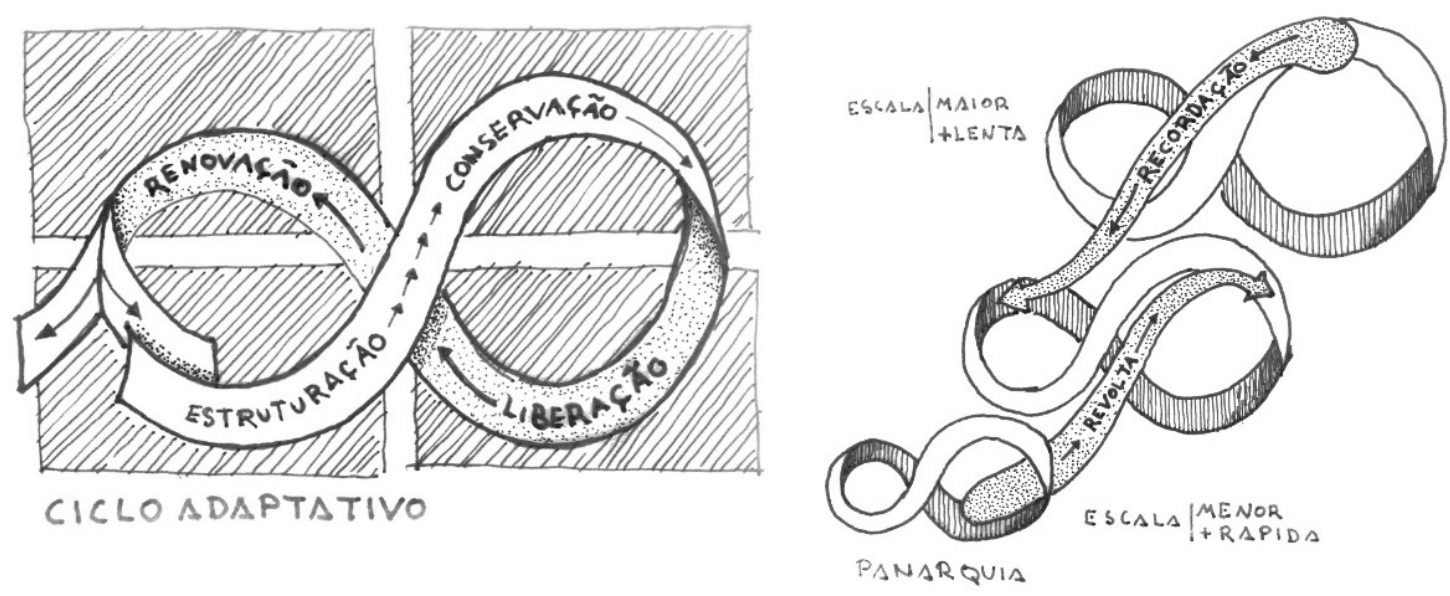

Figura 2 - Ciclo adaptativo e Panarquia, adaptado de Gunderson e Holling, 2002

A contribuição que este modelo nos traz é o reconhecimento da coexistência entre equilíbrio e mudança. As grandes transformações não se dão necessariamente a partir de decisões tomadas nas escalas superiores de governança. Podem e devem surgir nas comunidades e dos processos ecossistêmicos que ocorrem na escala das comunidades. Isto implica no reconhecimento destes processos, naturais e antrópicos, o que deve resultar em decisões importantes que inspirem gestões ambientais, assim como projetos ecológicos de arquitetura e urbanismo. Podemos listar alguns atributos importantes que contribuem a esta dinâmica e devem existir em ecossistemas urbanos resilientes (LOTUFO, 2016):

- Diversidade. Desde a biológica à econômica, passando pela social e cultural.

- Variabilidade ecológica. Livre da rigidez formal, os processos ecológicos no ambiente urbano devem fluir através de ciclos adaptativos. Isto exige presença 
de áreas verdes naturalistas e espaços públicos democráticos para o convívio social, flexíveis e de múltiplo uso.

- Modularidade. Em oposição à uniformidade racionalista o desenho urbano ecológico se define como um mosaico dinâmico de lugares diversificados, o que impede o desencadeamento rápido de distúrbios, e possibilita a cooperação das partes não afetadas.

- Capital social. Criado através de estímulos às interações em rede social, à formação de lideranças locais e à participação comunitária.

- Serviços ecossistêmicos. Fornecidos principalmente pela infraestrutura verde na gestão hídrica e do verde, na oferta de espaços públicos verdes, no controle da temperatura e da poluição.

- Mobilidade, transporte sustentável e acessibilidade. Cidades caminháveis, livres de poluição e ruído excessivo. Integração das diversas escalas de locomoção através de sistemas multimodais.

- Corredores e caminhos verdes. Caminhos para fluxos humanos e de biodiversidade, incluindo estradas, avenidas, ferrovias, ruas, ciclovias, acessos locais e margens de rios.

- Espaços Públicos Verdes. Espaços abertos multiuso, para lazer, esporte, convívio e iniciativas comunitárias.

- Construções Ecológicas. Além de cumprirem sua função social oferecem suporte às funções ecossistêmicas.

\section{Forma e fluxo - Conciliando tendências urbanísticas}

A arquitetura deve cumprir suas funções programáticas, sociais, culturais e econômicas, sem comprometer o fluxo das funções do ecossistema no qual ela se insere. $E$ deve, na medida do possível, lhe dar suporte.

"Forma segue função" é ainda uma formulação válida, mas torna-se necessária, e aqui propomos, uma ressignificação desta fórmula. Para o propósito ecológico devemos ir além das funções estabelecidas em um programa arquitetônico tradicional. Devemos incorporar ao programa aquelas funções que dão suporte a um ecossistema urbano sadio. 
Em um ecossistema urbano, como nos naturais, o fluxo de seus processos é um problema fundamental. Suas obstruções são patologias que causam mudanças nocivas à qualidade da vida na cidade. $\mathrm{O}$ ciclo das águas, a ventilação, a dispersão da biodiversidade, a luminosidade são alguns dos fluxos naturais. A mobilidade, a acessibilidade, o acesso a moradia, trabalho, educação e cultura, a economia, informação, destinação de resíduos etc. são alguns dos fluxos humanos.

Uma vez reconhecidos os fluxos, uma análise cuidadosa da forma urbana e arquitetônica poderá revelar quais obstruções estão enfraquecendo a resiliência do sistema. Um "desenho para os fluxos" tem como objetivo criar as condições espaciais para o desenvolvimento de uma vida social saudável na qual habitação, trabalho, cultura, lazer, esporte, encontro e convívio coexistam através do livre fluxo e confluência de seus processos. Uma arquitetura ecológica deve restaurar, preservar e harmonizar os fluxos inerentes ao ecossistema no qual se insere.

Os atributos da cidade tradicional, defendidos por movimentos como o New Urbanism e por pensadores importantes como Janes Jacobs e Jan Gehl, resgatam preceitos importantes, inerentemente humanos, que dão suporte a processos fundamentais ao ecossistema urbano, principalmente no que se refere à escala dos bairros e comunidades, à requalificação do espaço púbico e sua reconquista pelas pessoas. No entanto, não raro, esta abordagem tende a não considerar de forma satisfatória o papel da natureza na cidade, condicionando as áreas verdes em molduras rígidas, espaços fragmentados, desconexos, uniformes e ecologicamente frágeis.

Também na busca por um urbanismo mais sustentável, uma outra tendência do pensamento urbanístico contempla cenários futuros inéditos, principalmente nas escalas maiores, urbanas e regionais, ou em vazios urbanos subutilizados. Procura lidar com temas atuais, como a complexidade, a incerteza, mudanças climáticas, grandes infraestruturas. Dá grande ênfase aos processos ecossistêmicos e ocupa-se em superar a separação rígida entre arquitetura e paisagem. O movimento Landscape Urbanism é um exemplo desta abordagem que, por sua vez, falha em não contemplar de maneira satisfatória as escalas onde ocorre a vida cotidiana das pessoas e a dinâmica das comunidades.

São tendências aparentemente contraditórias. Se a primeira enfatiza a relação cidade-pessoas, a segunda enfatiza a relação cidade-natureza. Pode-se dizer que cada uma dá prioridade, respectivamente, à forma e ao fluxo. Propomos solucionar este 
dilema a partir de uma relação tríade: construções-natureza-pessoas (fig.03). É uma abordagem que propõe olhar passado e futuro simultaneamente, a partir do presente.

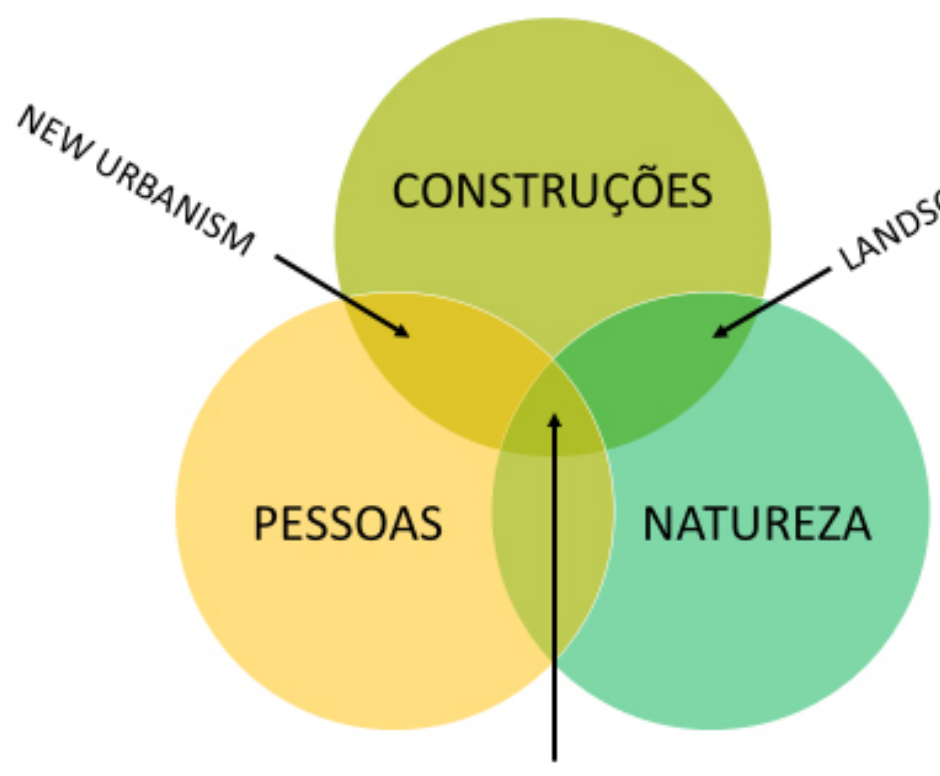

RESILIÊNCIA ECOLOGICA URBANA
Figura 3 - Integração de tendências

Da contradição entre as necessidades humanas e as ambientais deve emergir uma resposta ecológica conciliadora. Esta tríade construções-natureza-pessoas não é nova. Foi contemplada na gênese do pensamento organicista do urbanismo moderno, ainda no século XVIII, no movimento inglês pelo Pitoresco. A visão de cidade tradicional do movimento pelo Pitoresco, como foi apresentado nos estudos de Pevsner nos anos 50 (2010), inspira conciliar estes três componentes através de uma sensibilidade que falta àquelas duas tendências. Difere do movimento New Urbanism por não estar contaminada pelo racionalismo moderno e pelo historicismo pós-moderno. Difere do Landscape Urbanism por trazer à escala humana problemas ecológicos que este contempla em escalas maiores (LOTUFO, 2016).

Oferece assim à escala comunitária atributos que estão atualizados no conceito de resiliência ecológica: A variabilidade das formas urbanas desde o desenho dos edifícios, passando pela largura das ruas e soluções de calçadas, arborização, formato das quadras, praças e jardins; a diversidade do uso do solo e das soluções estéticas que conferem aos lugares características únicas e marcantes; a irregularidade dos caminhos que reservam surpresas e enriquecem a experiência de quem vive e circula 
na cidade; a estética naturalista, que é assimétrica e complexa. Por fim, nos mostra a relevância da experiência empírica e da sensibilização às funções ecológicas e culturais do lugar, principalmente na escala dos bairros e comunidades; inspira adaptações ecológicas profundas para a escala dos bairros, para as propostas contemporâneas de adensamento e a reconquista do espaço público pelas pessoas.

\section{A comunidade como componente ecossistêmico}

A falta de afetividade e interesse entre as pessoas, e destas com o lugar, tem importante protagonismo no estado calamitoso das cidades (HILLMAN, 1993). A negação da cidade hoje em dia se dá, antes de tudo, como negação do espaço público. Condomínios fechados e shopping centers são exemplos reais e simbólicos de um fenômeno que precisa ser revertido. São ilhas de exclusão que interferem nos fluxos dos processos ecossistêmicos, naturais e culturais, que humanizam o campo social. Decorre disto uma estética desprovida de ética, uma estética do medo e da insegurança, com seus muros altos, suas cercas eletrificadas, arames farpados, seguranças armados, carros blindados, onde deveria haver conexão e fluidez. Como disse Hillman "a frustação da alma, em face à uniformidade e impessoalidade de grandes muros e torres, destrói, como um bárbaro, aquilo que não pode compreender (...) Por nossa saúde psíquica e bem-estar de nossas cidades, continuemos a encontrar maneiras de abrir espaço para a alma".

Um desenho urbano que não contemple a adequação do lugar para as relações humanizadoras de convívio, afeto e participação comunitária enfraquece a resiliência, tornando a cidade ecologicamente frágil. Precisamos de espaços abertos aos fluxos que constroem o capital social.

Uma rua de tráfego pesado é hostil às pessoas. Isto melhora se houver segregação entre automóveis e pedestres, redução da velocidade de veículos, segurança para a circulação de bicicletas, calçadas largas e bem construídas. Melhora se houver na rua atividades que a mantenham viva e ocupada, sombra de árvores, presença do verde, lugares para descanso com mobiliário urbano bem desenhado. Mas o valor destes atributos se multiplica quando o fluxo humano se descondiciona do fluxo dos veículos motorizados.

Os caminhos para as pessoas, assim como o de outros fluxos, podem ser outros que os do automóvel. Podem ser mais pitorescos, sinuosos, com surpresas e espaços di- 
versificados para encontros, repouso, convívio, atividades sociais, culturais e de lazer. Isso se torna possível quando a quadra urbana se abre para a cidade e seu térreo é tornado público. Projetos arquitetônicos que contemplem a escala da quadra têm enorme potencial de inovação, tanto para a humanização do espaço urbano como para a integração do edifício com a infraestrutura verde. A quadra aberta se apresenta como a antítese ao condomínio fechado.

\section{A quadra urbana nas 'buffers zones', proposições na bacia do Córrego Mandaquí}

O conceito de Infraestrutura Verde, conforme Benedict e McMahon (2006), descreve um esquema simplificado composto por três elementos: Os núcleos, que correspondem aos parques e reservas florestais; os sítios, que correspondem aos jardins, praças e pequenos parques; e as conexões, que são corredores ecológicos, vias arborizadas, caminhos verdes, e parques lineares que conectam sítios e núcleos. Podemos adicionar a este modelo os amortecedores climáticos, ou buffers zones, que são os bairros jardins ou suficientemente arborizados.

As buffer zones devem ocupar os espaços entre os sítios, núcleos e conexões. Sua função é aumentar a área de influência da Infraestrutura Verde sobre o tecido urbano e diminuir o impacto do tecido urbano sobre as áreas verdes, rios e córregos, diluindo a fronteira rígida entre construção e paisagem. Quando as bordas da Infraestrutura Verde são projetadas com princípios ecologicamente orientados elas se transformam em buffers zones. Este estudo objetiva oferecer diretrizes para a criação de buffers zones na Bacia Hidrográfica do Córrego Mandaquí, na cidade de São Paulo.

Selecionamos um fragmento da cidade às margens do córrego Mandaquí numa área que abrange parte dos bairros do Limão (a Oeste do córrego) e Casa Verde (a Leste do córrego). Dentro deste fragmento assinalamos algumas quadras. $\mathrm{O}$ critério de escolha foi o de apresentar situações diversificadas de relevo e uso do solo, dentro da "Trilha Norte-Sul", faixa determinada pela pesquisa "Infraestrutura Verde para a Resiliência Urbana às Mudanças Climáticas da cidade de São Paulo" ao qual este trabalho se vincula. (fig.04) 

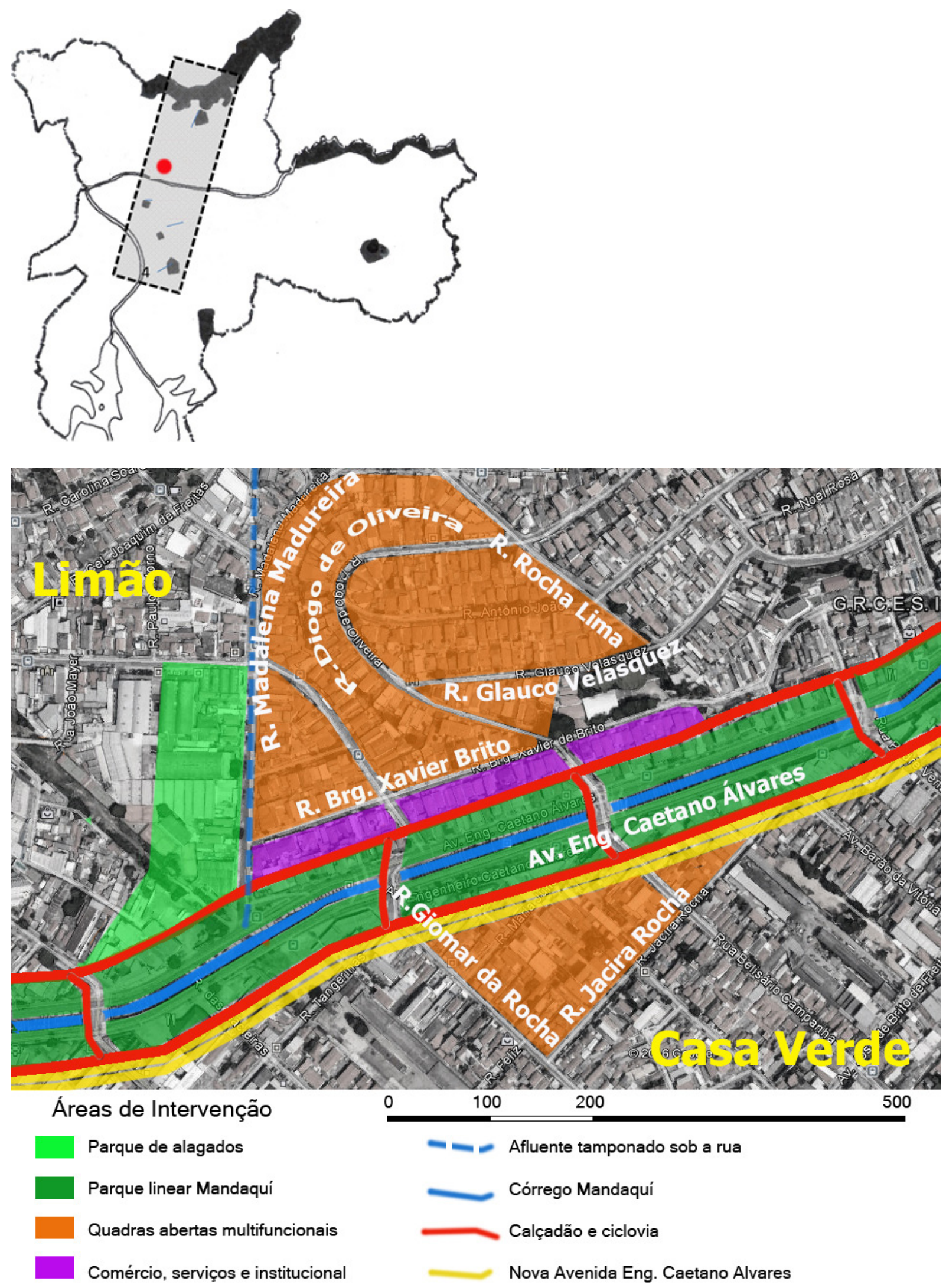

Figura 4 - O ponto vermelho na imagem superior sinaliza o local selecionado dentro do Recorte espacial do projeto "Infraestrutura Verde para a Resiliência Urbana às Mudanças Climáticas da cidade de São Paulo" 


\section{Córrego e parques fluviais}

Um cenário ideal para a transformação da Bacia Hidrográfica do Córrego Mandaquí apresenta a recuperação das margens do córrego como um parque linear contínuo, um corredor verde que conecta o Parque Estadual da Cantareira ao Rio Tietê.

Propomos que este parque linear apresente alargamentos nos pontos onde o Córrego Mandaquí recebe seus afluentes. Um destes alargamentos se situa na área de estudo, e deve abrigar um parque com a função específica de tratar a água do afluente e ser aberto à visitação pública. Devido sua fragilidade ecológica este parque deve dispor de caminhos e áreas de estar elevados sobre deck e passarelas. Lagoas pluviais e alagados compõe um pequeno sistema de purificação da água e controle de enchentes. Com vegetação ciliar, plantas macrófitas, fauna e flora da biota original, formará um ecossistema para recuperação da biodiversidade no meio urbano. O local é a quadra situada entre a Avenida Engenheiro Caetano Álvares, a faixa de servidão da Eletropaulo e a Rua Madalena de Madureira, hoje ocupada por galpões industriais. Esta quadra é o local da passagem original deste afluente, hoje poluído e canalizado sob a Rua Madalena Madureira.

O Parque Linear do Mandaquí deve conquistar seu espaço com a reestruturação do sistema viário, fundamentalmente pelo afastamento da Avenida Engenheiro Caetano Álvares. Suas duas pistas devem ficar afastadas 30 metros da margem leste do córrego, receber um canteiro central arborizado e biovaletas em toda sua extensão. Junto com outros dispositivos de drenagem ecológica, dispostos de acordo com a especificidade de cada lugar, devem compor um sistema que intercepte o fluxo horizontal das águas pluviais, protegendo o córrego da sujeira dispersa das ruas e calçadas. Podemos observar que ainda hoje restaurantes e oficinas mecânicas ao longo da Avenida Caetano Álvares, às margens do córrego, lançam óleos e graxas diretamente nas águas do córrego (fig. 05).

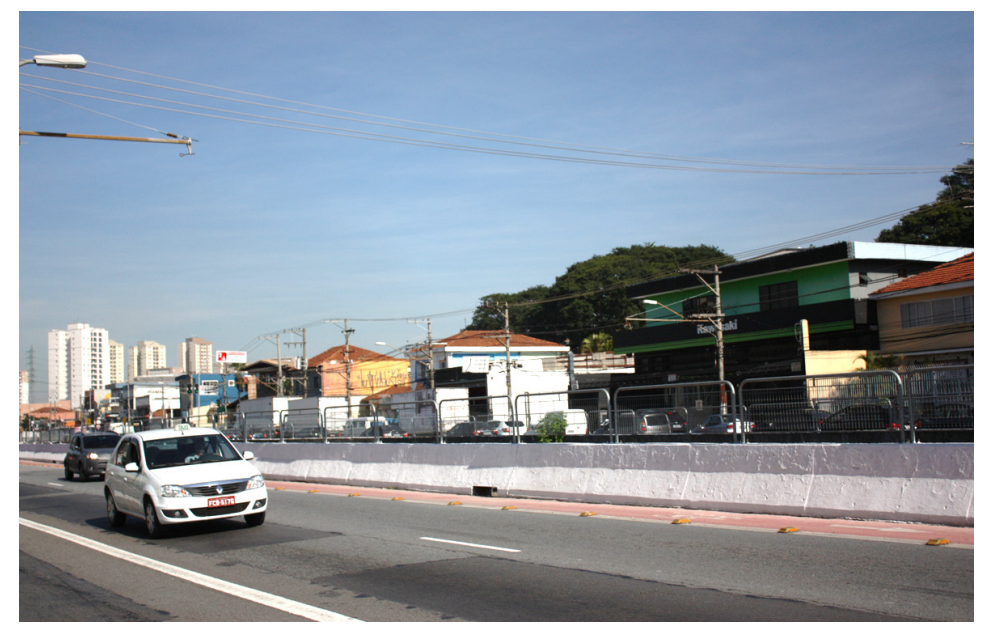

Figura 5 - Comércio e serviços automotivos às margens do Córrego Mandaquí (foto do autor) 
Hoje o córrego corre aberto sobre calha de concreto em grande parte de sua extensão. Existe um vigamento no nível das avenidas unindo as duas paredes da calha, elemento que aprofunda a separação entre a população e a água, criando um anteparo visual para quem atravessa suas pontes (Fig.06). A naturalização deste curso d'água prevê a substituição destas estruturas de concreto através de técnicas apropriadas, passando por condições temporárias até a constituição final de suas margens com solo compactado e protegido de erosão por vegetação ciliar. Alguns acessos da população à água através de decks e escadas devem ser previstos. O rio passa assim a participar da vida e da paisagem urbana.

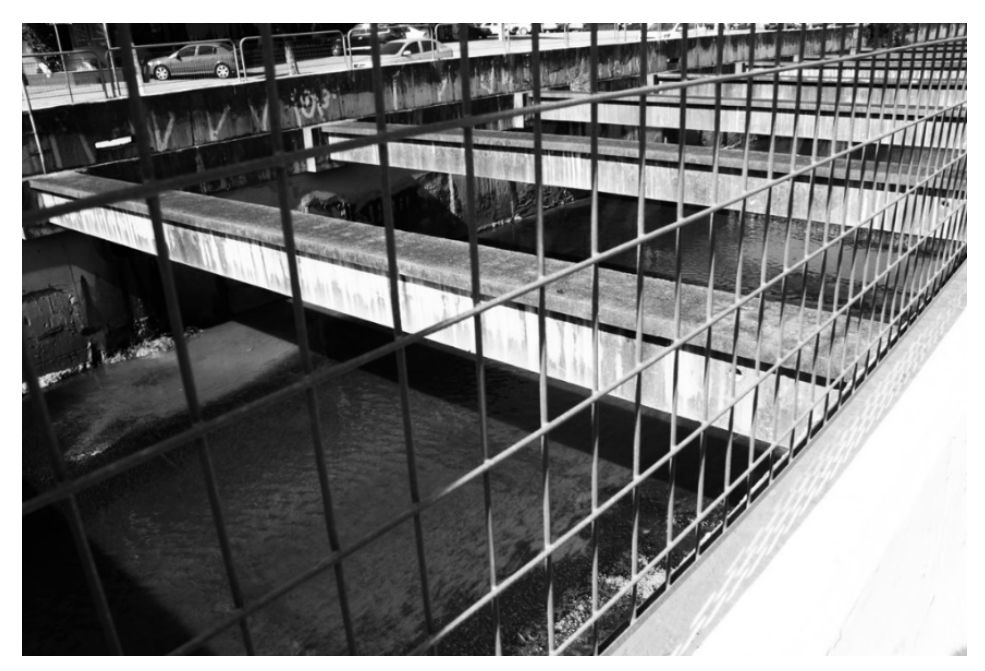

Figura 6 - Vigamento sobre calha concretada do Córrego Mandaquí (foto do autor)

Compondo com o parque linear, em toda sua extensão e em ambas as margens, um calçadão estará equipado com ciclovias sombreadas por árvores de espécies locais variadas, com suas copas se tocando. Mobiliário urbano durável e de excelente ergonomia estará disposto em ambientes para o encontro, sempre protegidos com o sombreamento natural de árvores. Bebedouros, lixeiras seletivas, quiosques com lanches e sucos, iluminação adequada, equipamentos de ginástica, quadras esportivas, pistas para skate e outros equipamentos completam a qualidade de um ambiente urbano que deve elevar radicalmente a qualidade de vida dos moradores locais e atrair visitantes de outros bairros.

\section{Quadras adjacentes ao parque}

As construções que fazem fronteira direta com o parque linear terão gabarito limitado a térreo e mezanino, e devem ter seus usos destinados ao comércio, serviço e institu- 
cional. Será estimulado e priorizado seu uso para educação e cultura, concentrando escolas, creches, bibliotecas, galerias de arte, auditórios, teatros, etc.

As quadras adjacentes ao parque linear entram para um programa de transformação urbana que deve ocorrer a longo prazo. Determina-se que toda nova edificação fica subordinada a um plano diretor de quadra.

\section{As Buffers Zones e o Plano Diretor Estratégico de São Paulo}

O projeto para o parque linear e o plano diretor para as quadras ecológicas deve incorporar diretrizes já determinadas pelo Plano Diretor Estratégico do município, além de novas diretrizes socioecológicas propositivas que objetivam sua constituição como buffers zones, isto é, como continuidade à Rede de Infraestrutura Verde.

Alguns objetivos que veem de encontro a presente proposta já estão descritos no Plano Diretor Municipal. Podemos destacar entre outros:

1. A redução da necessidade de deslocamento através da aproximação entre emprego e moradia;

2. A implementação de políticas fundiárias que criem alternativas à especulação imobiliária praticada pelo mercado, garantindo a função social do solo urbano e proteção do patrimônio ambiental;

3. A mitigação do impacto das mudanças climáticas, com estímulo à construção sustentável, proteção e promoção de áreas verdes e criação de novas áreas de proteção ambiental permanente;

4. A valorização e qualificação de espaços públicos verdes, arborizados e permeáveis.

5. O alargamento e qualificação das calçadas

6. O estímulo à "fachada ativa", que consiste no uso múltiplo no térreo dos edifícios,

7. A fruição pública do térreo,

8. As restrições às garagens,

9. A cota de solidariedade. 
Fundamentalmente nossa proposta se alinha a um dos elementos estruturadores do ordenamento territorial do Plano Diretor, a Rede Hídrica e Ambiental, ou seja, o sistema constituído pelos cursos d'água, seus fundos de vale, as áreas verdes e espaço livres.

O ponto principal, que demanda uma revisão no critério de adensamento, diz respeito aos rios urbanos, muitos deles canalizados. Enfatizamos nestas áreas o objetivo de coibir o processo de ocupação e adensamento nas várzeas, promover uma progressiva implementação de parques lineares fluviais e determinar critérios construtivos e de ocupação nas beiradas destes parques. Estes critérios estão fundamentados no objetivo de potencializar as funções ecossistêmicas desempenhadas pela Infraestrutura Verde, tomando a quadra ecológica como unidade fundamental estruturadora das buffers zones.

Como previsto no Plano Diretor, por tratar-se de área com grande potencial de transformação ao longo de orla fluvial, esta proposição pressupõe a elaboração de um Projeto de Intervenção Urbanística (PIU, art. 136 do PD) para a região, a ser formulado com participação conjunta entre academia e comunidade. Estas áreas, para cumprir efetivamente suas funções ambientais, deveriam ter seus critérios de ocupação apoiados em um Zoneamento Ambiental, como o proposto por Schutzer (2012), que determinaria um conjunto de preceitos específicos a cada local de acordo com a compartimentação do relevo e seus processos hídricos e geológicos inerentes. A remuneração por serviços ambientais, também previstas pelo Pano Diretor, deve estimular o mercado imobiliário a adotar em seus projetos os critérios de sustentabilidade determinados pelo PIU.

O Reordenamento Urbanístico Integrado (art. 134, § 2.0 do PD), que consiste na unificação dos lotes e mudança no parcelamento do solo é outro instrumento do Plano Diretor que pode ser usado na proposição das quadras ecológicas das buffers zones, com a justificativa de potencializar os serviços ambientais da Infraestrutura Verde. $O$ modo como um reordenamento no parcelamento do solo pode potencializar processos ecossistêmicos está descrito mais adiante.

Outro instrumento previsto para a implementação de um PIU é o AIU (Área de Intervenção Urbana, art.145 do PD). Este instrumento objetiva a transformação e melhoria ambiental nos entornos da Rede Hídrica e Ambiental. Como os corredores viários muitas vezes coincidem com os rios canalizados o adensamento da Rede Estrutural de Transporte Coletivo está frequentemente em conflito com a necessidade de preservação e recuperação de fundos de vale. Desta forma, criar meramente restrições à ver- 
ticalização nos miolos de bairro, como o Plano Diretor propõe, segue um critério mais tecnicista que pode, em determinadas circunstâncias, estar em conflito com objetivos ambientais. Nossa proposta para um PIU é que esta restrição se dê de forma escalonada a partir dos cursos d'água. Propomos que seja mais o relevo e Hidrografia, e menos o sistema viário, que determinem o critério de adensamento nos locais onde estas infraestruturas, naturais e técnicas, estão espacialmente sobrepostas. Este critério permitiria uma recuperação progressiva do Córrego Mandaquí e suas margens como parte de uma ampla Rede Municipal de Infraestrutura Verde. Com rios e córregos recuperados e participando novamente da paisagem, com seus parques lineares livres de edificações, criando continuidade e conexão (caminhos verdes) entre os núcleos e sítios, e expandindo a zona de influência da Infraestrutura Verde através das buffers zones determinadas em suas margens, estas áreas devem ter toda e qualquer construção rigorosamente projetada por critérios ecológicos.

Estabelecemos alguns critérios para fundamentar o plano diretor de quadras.

Permitir:

1) Projetos arquitetônicos globais, para toda a quadra

2) Dois ou mais projetos arquitetônicos para a mesma quadra, desde que integrados no mesmo plano diretor

3) Anexação de duas ou mais quadras, desde que acompanhada com propostas viáveis de restruturação viária

\section{Exigir:}

1) Térreo público e de uso múltiplo

2) Quadra aberta

3) Integração de áreas livres e promoção de espaços de convívio

4) Ausência de subsolo com concentração de estacionamento em edifício único por quadra

5) Mínimo de $50 \%$ de área livre, verde e permeável

6) Teto verde ou composto com soluções para produção de energia renovável

7) Atendimento à função de suporte e continuidade às funções desempenhadas pela Infraestrutura Verde, funções estas determinadas por Zoneamento Ambiental (SCHUTZER, 2012)

8) Projeto habitacional com cotas de solidariedade e prioridade de aquisição à população já residente 


\section{Sistema ecológico de drenagem}

Importantes elementos que compõe a Infraestrutura Verde na escala local, os dispositivos de drenagem ecológica, devem ser implementados em todo entorno e interior das quadras, conforme sugerido pelas compartimentações de relevo (como veremos adiante). Correspondem aos jardins de chuva, canteiros pluviais, biovaletas, lagos pluviais, bacias de retenção, vias relvadas, pavimentação permeável, alagados, microestações de tratamento de esgoto e dispositivos incorporados às construções. $A$ ideia é que o sistema de circulação e espaços livres, assim como os edifícios, abrigue também um sistema de drenagem ecológica (LOTUFO, 2016). A capacidade de retenção, contenção e reuso do sistema aproxima a cidade daquilo que Bunster-Ossa (2013) chamou de "cidade esponja".

\section{Esgoto}

Microestações de tratamento de esgoto contribuem com a descentralização de grandes redes de infraestrutura, evitando extensas tubulação e bombeamento às estações remotas de grande porte. Seus subprodutos, energia e fertilizantes, devem ter destinação local para iluminação pública e manutenção das áreas verdes. Estas microestações podem ser construídas no local ou adquiridas de indústrias especializadas. Em tamanhos variados, podem atender desde a escala de condomínios e quadras inteiras até a de residências unifamiliares. Para que possam ser implementadas na cidade de São Paulo ainda seria necessária uma restruturação na legislação, o que possibilitaria grandes ganhos ambientais.

\section{Edificando nas buffers zones}

Os projetos arquitetônicos que se situam nas quadras das buffers zones devem dar suporte e continuidade às funções da Infraestrutura Verde. Além de suas funções programáticas convencionais inclui a diminuição da ilha de calor, a gestão dos recursos hídricos, a captura de carbono, oferta de rotas de dispersão para biodiversidade, oferta de espaços verdes públicos, a saúde preventiva da população, entre outros benefícios. Funções a serem desempenhadas tanto nas áreas construídas como nas áreas livres remanescentes. Nas construídas através de coberturas, terraços e fachadas verdes, que podem estar isolados ou, preferivelmente, dispostos em escadas ecológicas, atra- 
vés do escalonamento das edificações. Esta continuidade pode se dar também sob pilotis, conquistando uma taxa de permeabilidade relativa mesmo sob as construções.

Este incremento no potencial de permeabilidade sob os edifícios se dá pela capilaridade da terra, e artificialmente pela infraestrutura de contenção e percolação dos jardins de chuva que podem se estender para baixo do edifício. As passagens sob piloti servem tanto ao fluxo de pessoas como ao da biodiversidade, com jardins sombreados que reintroduzem as espécies que vivem no solo e sob a sombra das árvores, e conectam as áreas vegetadas das calçadas ao núcleo da quadra (fig.07).

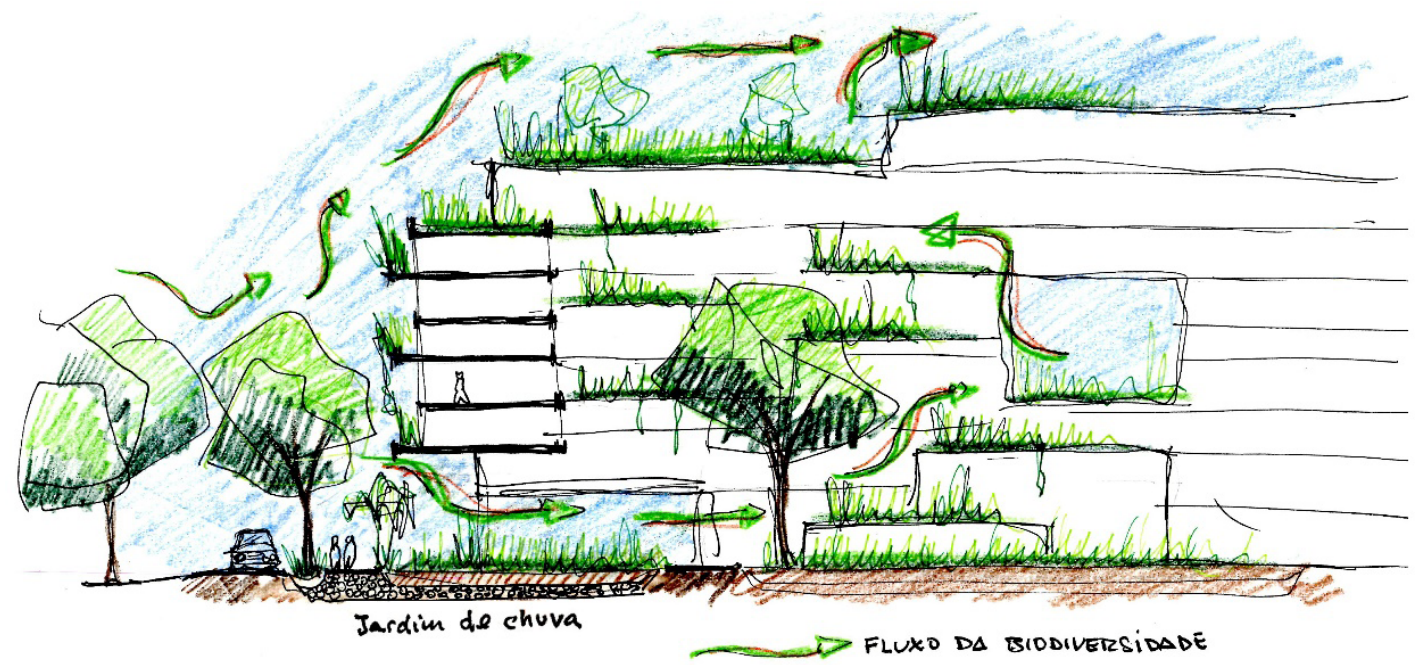

Figura 7 - Fluxo da biodiversidade (LOTUFO, 2016)

Nas áreas livres devem-se potencializar a permeabilidade do solo e a contenção das águas, através de jardins de chuva e canteiros pluviais. Cisternas devem receber a água da chuva já filtrada por estes dispositivos e pelas coberturas verdes. O excedente deve retornar ao solo para a reposição de lençóis freáticos. Só quando o volume de água superar a capacidade do sistema ecológico, o excedente é conduzido à infraestrutura convencional de drenagem, que deve permanecer como dispositivo de apoio.

O princípio de quadra aberta estabelece uma relação mais direta entre as áreas livres do interior da quadra e o sistema de circulação. A infraestrutura de circulação dá continuidade também àquelas funções desempenhados pela Infraestrutura Verde através de dispositivos de drenagem ecológica nas ruas e calçadas. São os canteiros pluviais, biovaletas e jardins de chuva, assim como a pavimentação permeável. Dispostos ao 
longo das calçadas interceptam o escoamento superficial e aumentam o índice de permeabilidade. $O$ conjunto de quadras abertas, calçadas altamente qualificadas e dispositivos ecológicos de drenagem cria um desenho de espaço público de elevada qualidade socioambiental (LOTUFO, 2016) (fig.08).
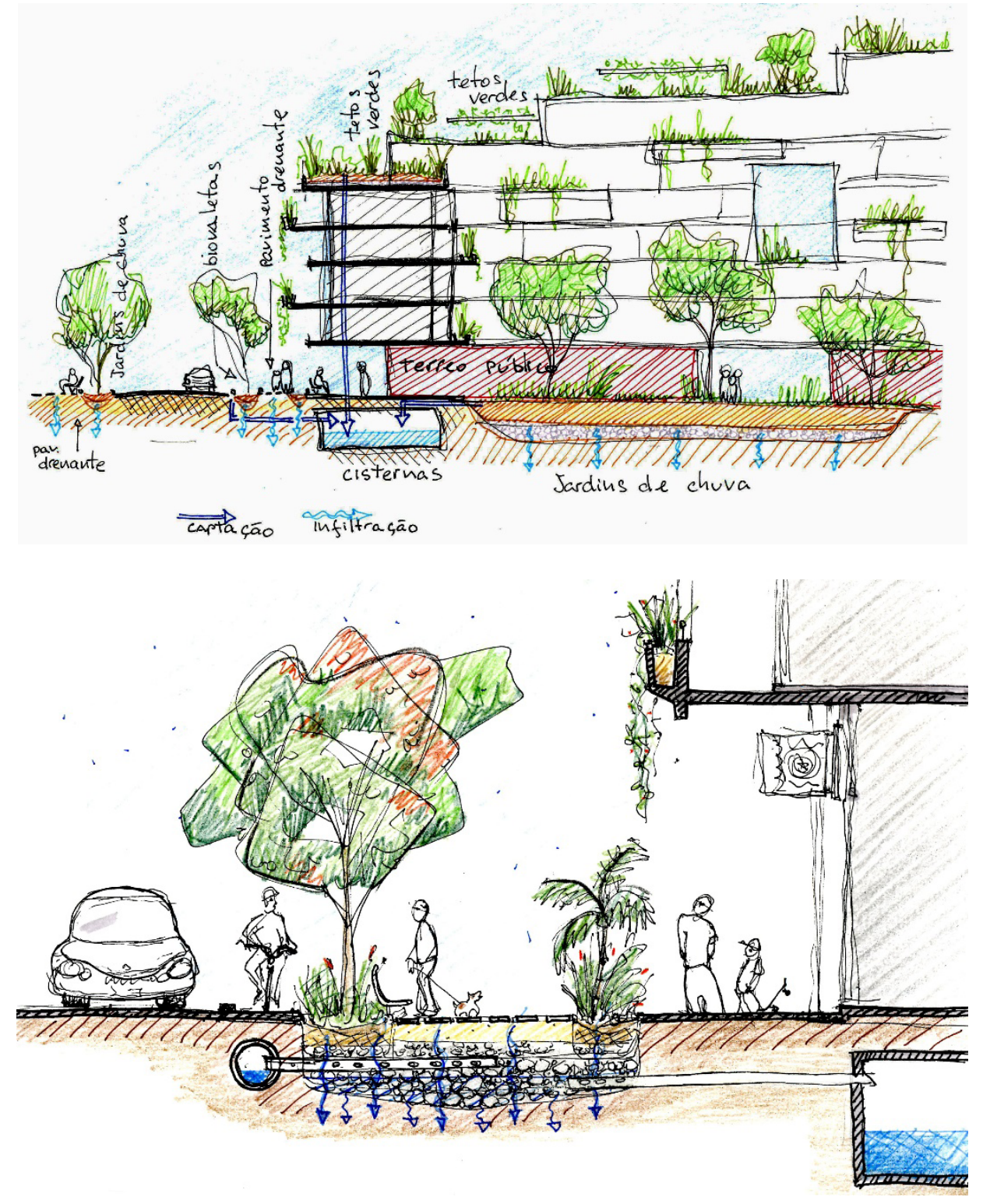

Figura 8 - Qualificação socioambiental do espaço público (LOTUFO,2016)

\section{A quadra como unidade de desenho urbano}

As transformações urbanas em andamento, principalmente na cidade de São Paulo, seguem a tendência de construção de condomínios fechados com edifícios vertica- 
lizados no centro do lote. Para que esta tendência seja revertida é necessária uma reformulação da lei de uso do solo, pela qual as quadras, e não mais o lote, se tornem as unidades fundamentais do desenho urbano. Na margem Sul do Rio Tietê o desenvolvimento urbano, regido pelo mercado imobiliário, já apresenta forte verticalização, com projetos de grandes condomínios, alguns com cinco ou seis torres no mesmo empreendimento. Isolados da cidade por extensos muros contínuos, negam o valor da rua e do espaço público. Ao Norte do Rio Tietê, onde nosso estudo se situa, ainda há grande potencial para a reversão desta tendência. Mas já surge no skyline o contorno das primeiras torres (fig.09).

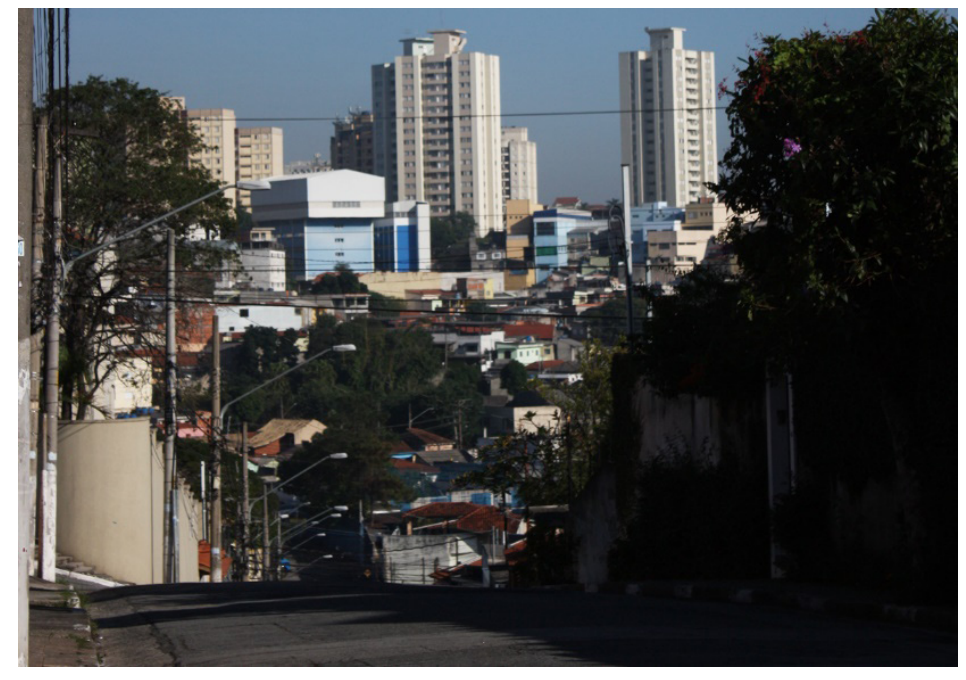

Figura 9 - Mercado Imobiliário se acercando na região. Vista da Rua Rocha Lima. (foto do autor)

Os ganhos socioambientais de se projetar espaços integrados, em recortes maiores de território, são diversos, desde que não sigam esta tendência isolacionista dos grandes condomínios fechados. Os interesses da coletividade não podem ser sobrepujados pelos interesses particulares dos que só se importam com a cidade como ativo econômico. Esta economia que trata solo urbano como mercadoria especulativa é um grande empecilho aos processos reguladores do ecossistema urbano.

Nossa proposta parte do pressuposto de uma reformulação da lei de uso e ocupação do solo, pela qual só será possível desenvolver projetos de edificações para uma mesma quadra quando esta for aberta e integrada à cidade, com acesso público ao térreo de múltiplo uso. Os projetos devem ser precedidos e vinculados a um projeto piloto para a totalidade da quadra. O objetivo é integrar a construção de modo a potencializar suas qualidades sociais e ecológicas. 
O perímetro de uma quadra urbana geralmente define um limite rígido entre o espaço público e privado; uma barreira murada que restringe o espaço do pedestre às calçadas ao longo das vias, junto ao fluxo de veículos, o que pune o pedestre com poluição, ruído e insegurança. A função do espaço público fica restrita à locomoção, desqualificando-o como espaço para acontecimentos sociais. O núcleo da quadra, por sua vez, permanece inacessível e subutilizado no domínio privado.

O loteamento usual de uma quadra urbana em São Paulo define um conjunto de barreiras (muros) que fragmenta o espaço privado em porções pequenas e individualizadas. Condiciona, através de recuos obrigatórios, e do potencial construtivo, a implantação de torres no centro do lote. A permeabilidade do solo é reduzida pela pavimentação e pela existência de subsolo sob grande parte das áreas livres remanescentes. O sombreamento das torres prejudica a vegetação. Como acessos tímidos aos fundos do lote, estas reminiscências pouco prestam ao lazer e convívio, permanecendo, a maior parte do tempo, vazias e subutilizadas. Resulta, de modo geral, numa perda significante do potencial social e ecológico das áreas livres.

Esta restrição é revertida quando a quadra, e não mais o lote, se torna o bloco básico do tecido urbano, e seu núcleo aberto é oferecido como um espaço integrado, de uso múltiplo, coletivo, verde e permeável (LOTUFO, 2016) (Fig.10).

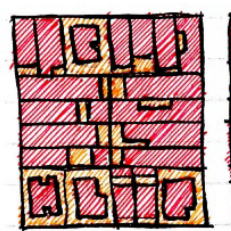

שI CONSTRUGĀO QUADRA CONVENSIONAL

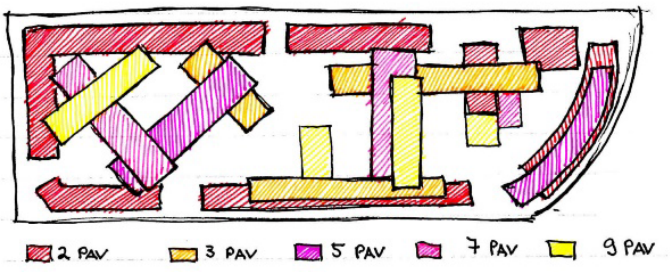
ESCALONAMENTO DOS EDIFÍCIOS

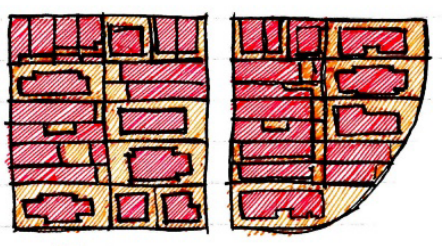

DSARA LIVRE

Figura 10 - Potencial para novos fluxos de uma quadra aberta (LOTUFO, 2016)
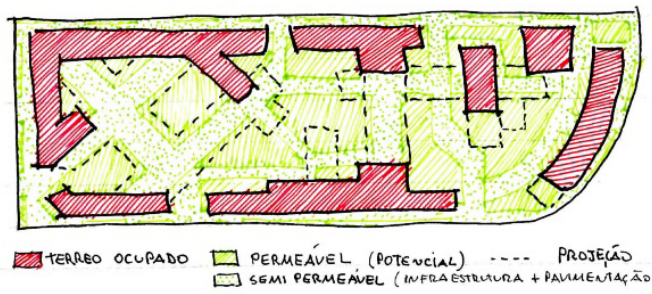

QUADRAS INTEGRADAS : OCUPAÇÃO DO TÉRREO E PROJEÇÃO DO EDIFICIO

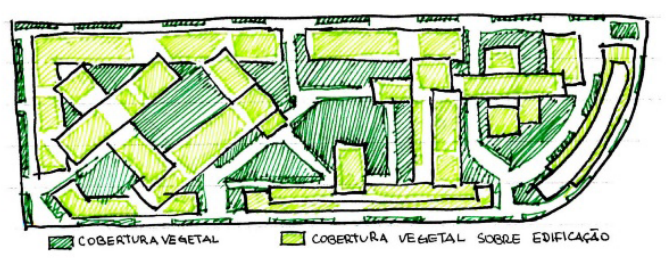

ÁREAS VERDES, PERMEÁVEIS E SOBRE LAJE 
O conceito de permeabilidade da quadra deve incluir e extrapolar a questão hídrica, abrangendo o conjunto dos fluxos ecossistêmicos, tanto naturais como humanos. Enquanto a quadra convencional tende a condicionar os fluxos no sistema viário em torno de si, a quadra aberta possibilitará grandes ganhos para o sistema de circulação. Transitar através das quadras e acessar a diversidade de usos em seu interior traz ganhos na mobilidade e acessibilidade, além de contribuir para a reconquista da cidade pelas pessoas. A quadra aberta estende a calçada e a fachada ativa ao seu núcleo por caminhos restritos a pedestres. Ao expandir as possibilidades de fluxos no interior da quadra dissolvemos a rigidez da trama viária criando novas possibilidades de trajetos. Aumentando a possibilidade de eventos físicos, biológicos e humanos criamos as condições para o incremento da resiliência urbana, tanto no âmbito social como ecológico.

\section{Estacionamento e circulação}

O uso misto no nível térreo proverá as condições do que se convencionou chamar de cidade compacta. Quando a habitação está em proximidade com a escola, comércio, serviços, oportunidades de emprego, lazer, esporte e cultura, diminui consideravelmente a necessidade de locomoção motorizada e transporte público. Isto alivia a pressão sobre o sistema de circulação, e demanda sobre a mobilidade e transporte.

Com a quadra como unidade territorial, um só edifício concentra o estacionamento para veículos. Com acesso único para os automóveis, as calçadas ficam exclusivamente para a circulação das pessoas, sem os numerosos acessos inconvenientes, com melhores possibilidades para mobiliário e soluções paisagísticas. Pode-se assim planejar caminhos, por exemplo, da casa à escola e ao parque, livre de veículos pesados e poluentes, ou de cruzamentos perigosos. As crianças poderão voltar à rua e redescobri-la como lugar da infância (fig.11) 


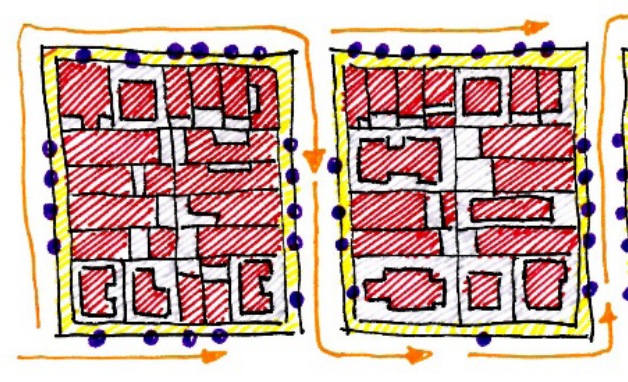

QUADRA CONVENSIONAL
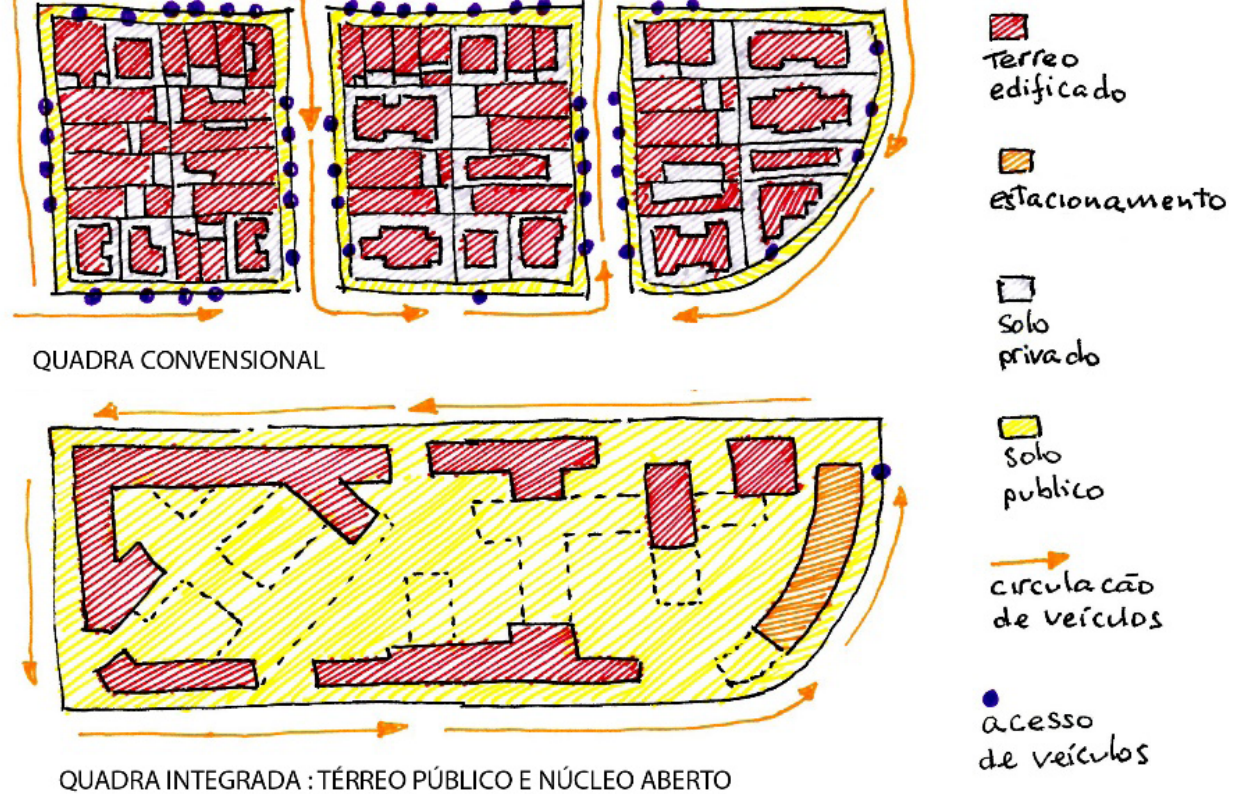

$\square_{\text {solo }}$

publico

circulacão

de veículos

acesso

de veículos

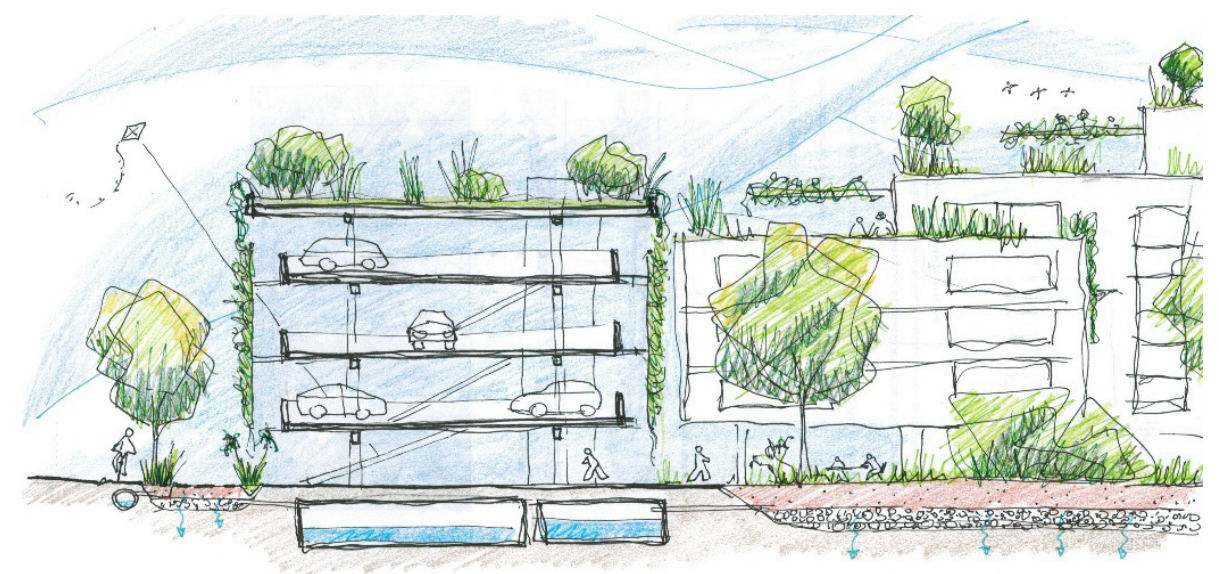

Figura 11 - Restrição aos veículos (LOTUFO, 2016)

A restrição à circulação de veículos pode possibilitar a união de duas ou mais quadras, assimilando no projeto global o espaço ocupado anteriormente pelas vias. Definem-se novos caminhos, não necessariamente ortogonais. Este recurso possibilita implantações mais livres da grelha viária e um aumento significativo da taxa de permeabilidade e de áreas verdes. O recurso do piloti permite que se crie fluxos de circulação independentes da implantação dos edifícios, através de passagens e áreas de convívio sob a construção, protegidas do sol e chuva. Equilibrados com a implantação de térreo multiuso e fachadas ativas, os pilotis serão as passagens ao centro da quadra, que poderá abrigar uma diversidade de usos semelhante aos da rua. 
As áreas privativas no térreo devem ser reduzidas ao que for necessário para o controle de acesso aos blocos residenciais. A segurança dos moradores é melhorada pela orientação das aberturas das unidades habitacionais à rua.

Preceitos de arquitetura bioclimática, com a potencialização da iluminação natural através da orientação adequada das aberturas, sombreamento com uso de brises e cobogós, varandas e beirais, ventilação cruzada e aeração adequada através de vãos e pilotis contribui na economia de energia, na dispersão de ilhas de calor e da poluição do ar. São elementos já bem conhecidos que recuperam e direcionam fluxos de ar e luminosidade. Estão subentendidos como preceitos fundamentais de projeto.

Quando o projeto da quadra se abre aos fluxos de pessoas, da biodiversidade, da luz, do ar e da água, flexibiliza-se a rigidez frequentemente imposta por soluções pouco ecológicas, baseadas num funcionalismo mecanicista e não sistêmico (fig. 12).

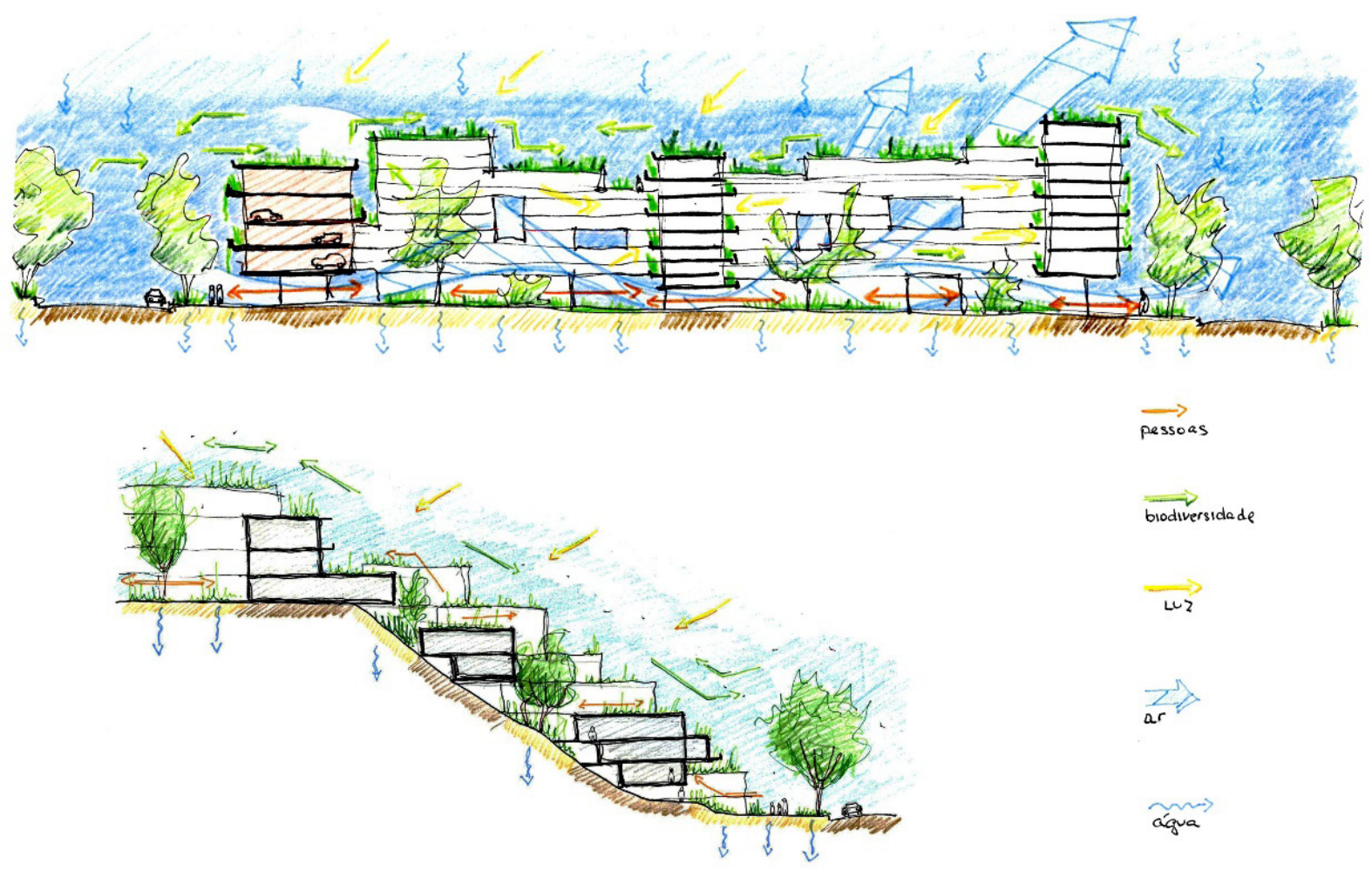

Figura 12 - Permeabilidade ao fluxos em áreas planas e colinas (LOTUFO, 2016) 


\section{Potencial de transformação das quadras}

O grau de verticalização das quadras determina sua consolidação e potencial de transformação, que será classificado como: alto, médio e baixo.

Onde há um alto potencial de transformação é possível recuperar o núcleo da quadra como área livre de edificação, construir ou renovar totalmente a quadra a partir do plano piloto.

Onde há médio potencial a presença de edifícios altos limita, mas não impossibilita, projetos integrados para a totalidade da quadra. É possível a mudança de uso no térreo, torná-lo de acesso público e integrar suas áreas livres. A configuração construtiva da quadra, neste caso, será uma solução híbrida entre o que já existe e preceitos ecológicos conquistados com retrofit e novas construções.

O potencial de transformação é bem menor onde as quadras já sofreram elevado grau de verticalização e as torres altas já condicionaram por demais a configuração da quadra. Ainda assim, será possível converter as áreas comuns do térreo em espaços públicos com mudanças para uso múltiplo. Se retirados os muros que separam os lotes, é possível integrar os recuos laterais e de fundo, convertendo-os em áreas livres e caminhos pitorescos mais propícios para o uso social (fig. 13).

A ausência de torres em nossa área de estudo determina, de forma geral, um alto potencial de transformação.

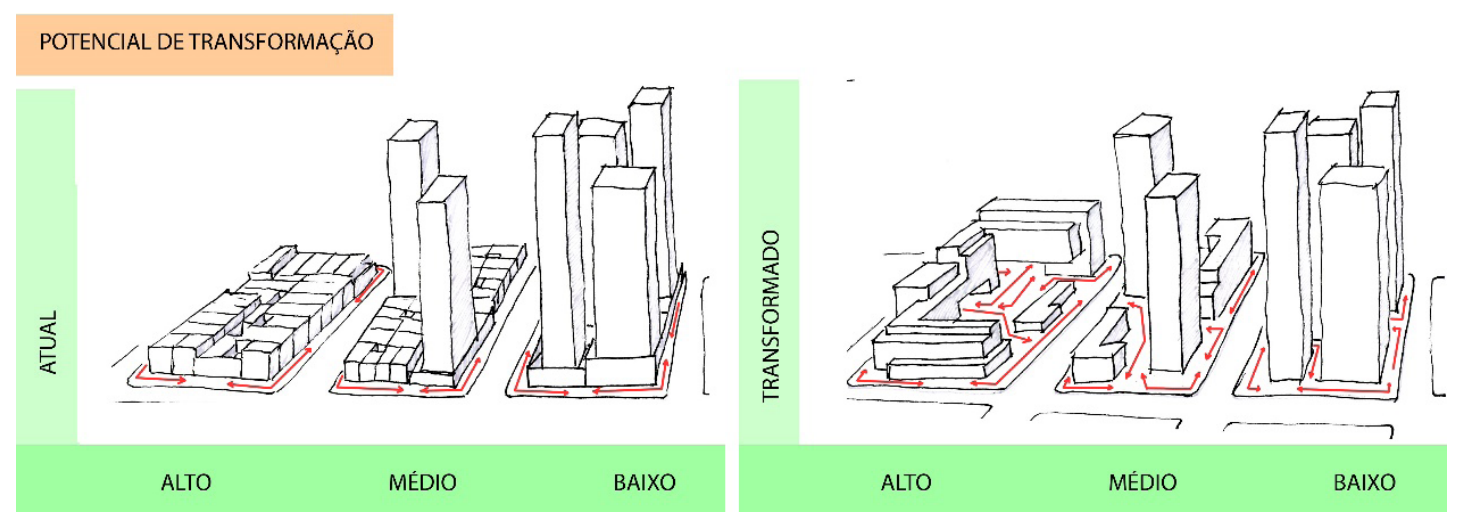

Figura 13 - Potencial de transformação (LOTUFO, 2016) 


\section{Dispositivos de Infraestrutura Verde incorporados às construções}

Alguns dispositivos de Infraestrutura Verde estão diretamente associados às construções ecológicas (LOTUFO, 2016). Estes dispositivos, além de oferecer grande incremento na área de superfície verde urbana, fornecem na escala da edificação os atributos da "cidade esponja" (BUNSTER-OSSA, 2013), a saber: a capacidade de absorver, reter, purificar, disponibilizar ao reuso ou devolver ao ciclo natural a água. Este conceito atribui ao projeto arquitetônico a importante função de contribuir na gestão hídrica, na diminuição das ilhas de calor e na oferta de espaços verdes.

- Tetos verdes. Tanto podem ser projetados para edificações novas como para reformas, e oferece soluções para casos específicos, em laje ou telhado, com camadas de solo ou substratos que variam de 5 a $60 \mathrm{~cm}$, possibilitando desde o plantio de musgos e herbáceas até árvores de pequeno porte. Entre as funções desempenhadas por este dispositivo está a retenção de água de chuva, filtragem para reuso ou retorno do excedente ao sistema tradicional de drenagem; isolamento térmico, resfriamento do entorno, captura de carbono, destinação para hortas urbanas, caminhos para polinização, migração de microfauna e dispersão de sementes.

- Terraços verdes e escadas ecológicas. Além de cumpriremas mesmas funções dos tetos verdes possibilitam o fluxo da biodiversidade para cima e através de edificações. Melhoram o microclima do entorno e diminuem a demanda por arcondicionado. Humanizam e trazem maior bem-estar ao ambiente de trabalho, diminuindo custos com saúde e aumentando a produtividade.

- Fachadas e muros verdes. Proporcionam uma continuidade vertical à superfície vegetada, possibilitando conexões de áreas verdes que se situam em diferentes níveis, do térreo às coberturas dos edifícios. Formam caminhos para polinização e migração de microfauna. Contribuem para amenizar a temperatura no interior dos edifícios e em seus entornos, retêm parcialmente a água da chuva e capturam carbono. Aumentam a área de superfície vegetada.

- Pátios internos ajardinados. Podem existir sobre o solo permeável ou sobre eventuais subsolos construídos. Podem abrigar dispositivos como jardins de chuva contribuindo contra enchentes e poluição de córregos e rios. A água captada pode retornar aos ciclos naturais ou ser conduzidas, já filtradas, às 
cisternas, para reuso. Quando sobre laje desempenham as mesmas funções de um canteiro pluvial, aumentam a oferta de áreas verdes para o convívio, lazer, esporte ou hortas. Além de sua função climática cumpre uma função social para a cidade, criando lugares tranquilos e seguros frente ao caos urbano.

- Cisternas. Têm como função coletar, conter e disponibilizar para reuso a água de chuva. A água coletada deve passar por processos de purificação e ser destinada aos diversos usos, como irrigação, limpeza e fins sanitários. $\mathrm{O}$ volume excedente pode se destinar aos sistemas de drenagem, tradicionais ou ecológicos. O sistema deve coletarágua das lajes, telhados, pisos pavimentados, ruas e calçadas, além de receber o excedente que outros dispositivos não conseguem conter. As cisternas podem ser construídas no local ou adquiridas pré-fabricadas em tamanhos que atendem desde uma residência unifamiliar até grandes edifícios. $\mathrm{O}$ uso sistemático de cisternas poderia nos garantir uma boa alternativa para a produção local de água, diminuindo a demanda dos mananciais principalmente em épocas de escassez.

Quando o projeto do edifício incorpora em seu programa o suporte e a continuidade das funções desempenhadas pela Rede de Infraestrutura Verde, ele estará a ela integrado. Edifício e paisagem então confluem (fluem junto).

\section{Compartimentações de relevo e soluções específicas}

Na vertente Oeste da bacia hidrográfica do Córrego Mandaquí o relevo se apresenta mais acidentado e podemos encontrar quatro compartimentações de relevo (SCHUTZER, 2012): fundo de vale, as vertentes de um pequeno morro, uma área tabular no topo do morro e uma área de nascente de uma micro bacia. Na vertente Leste, grande parte da área selecionada está em fundo de vale. Mais afastada do rio um pequeno recorte se encontra sobre uma área tabular livre de inundação. Esta compartimentação do relevo exige dos projetos arquitetônicos soluções distintas para dar suporte às funções hídricas da Infraestrutura Verde (fig.14). Bonzi (2015) sintetiza as funções de cada compartimento e os respectivos dispositivos recomentados.

Nos fundos de vale os solos estão permanentemente úmidos devido a superficialidade do lençol freático. Assim o armazenamento de água prevalece sobre a infiltração. 
O escoamento superficial se concentra no próprio córrego e nos tributários, assim como nos cursos sazonais. Os recuos ocupados pelo parque linear fluvial ficarão livre de construções, o que é o ideal para estas áreas naturalmente inundáveis. No entanto, devido sua extensão, em grande parte destas áreas haverá construções. Para evitar inundações deve-se observar a capacidade de retenção e infiltração nas áreas à montante (áreas tabulares e vertentes), que devem receber em larga escala os dispositivos de drenagem com esta função. O próprio recuo do córrego, agora recuperado como parque, cumpre a função de receber a água da chuva, inundando sem prejuízo à população. Recomenda-se para os fundos de vale os seguintes dispositivos (Tab.01):

\section{Tab.01}

DISPOSITIVOS DE DRENAGEM NOS FUNDOS DE VALE

\begin{tabular}{|l|l|}
\hline Nas edificações & Nas áreas livres e sistema viário \\
\hline & - Bovaletas \\
- Teto verde & - Canteiro pluvial (sem infiltração) \\
- Fachada verde & - Cisterna \\
- Terraços e escadas verdes & - Alagados \\
- Canteiro pluvial (sem & - Lagoa pluvial \\
- infiltração) & - Pavimento drenante \\
& - Córrego reabilitado \\
& - Parque linear \\
\hline
\end{tabular}

Nas áreas tabulares livres de inundação os processos de infiltração predominam sobre o escoamento superficial, o que deve ser potencializado ao máximo, junto aos processos de percolação (deslocamento da água através do solo), para filtragem e reposição do lençol freático. Deve haver controle sobre o escoamento superficial para garantir a qualidade da água que chega ao córrego, interceptando a poluição dispersa, e para controle de enchentes. Este controle se dá principalmente por dispositivos de detenção e retenção, para reuso ou liberação lenta. A densa arborização também é recomendada, que além dos outros benefícios conhecidos, aumenta a permeabilidade do solo e tem capacidade de reter parcialmente a água de chuva nas folhagens. Recomenda-se para áreas tabulares os seguintes dispositivos (Tab.02): 


\section{Tab.02}

DISPOSITIVOS DE DRENAGEM NAS ÁREAS TABULARES

\begin{tabular}{|l|l|}
\hline Nas Edificações & Nas áreas livres e sistema viário \\
\hline - Jardim de chuva & $\begin{array}{l}\text { - Jardins de chuva } \\
\text { - Teto verde }\end{array}$ \\
- Fachada verde & - Canteiro pluvial com infiltração \\
- Terraços e escadas verdes & - Alagados \\
- Canteiro pluvial com infiltração & - Pavimento drenante \\
- Cisterna & - Via relvada \\
\hline
\end{tabular}

Nas vertentes de morro predomina o escoamento superficial sobre a infiltração, acentuado pela impermeabilização do solo urbano. Onde há solo descoberto ocorre erosão e há alto risco de deslizamento. Por isso se recomenda densa arborização e implantação de praças e jardins, com terraceamento para controle do fluxo superficial. Para evitar deslizamentos, salvo as praças e jardins devidamente arborizados, não se recomenda solo permeável, sendo preferível dispositivos de contenção e retenção. Devido a cota elevada e o potencial de retenção é propício para a construção de reservatórios para tratamento e reuso. Recomenda-se nestas áreas os seguintes dispositivos (Tab.03):

\section{Tab.03}

\section{DISPOSITIVOS DE DRENAGEM NAS VERTENTES}

\begin{tabular}{|l|l|}
\hline Nas edificações & Nas áreas livres e sistema viário \\
\hline - Teto verde & $\begin{array}{l}\text { - Biovaleta } \\
\text { - Canteiro pluvial sem infiltração }\end{array}$ \\
- Cisterna & \begin{tabular}{l} 
- Canteiro pluvial sem infiltração \\
\hline
\end{tabular}
\end{tabular}

Nas áreas de nascente predomina escoamento superficial e a rigor deve ser área não edificável. Recomenda-se fundamentalmente a recuperação da vegetação com densa arborização. Quando em áreas densamente urbanizadas e já ocupadas pode-se 
construir reservatório, recuperar a permeabilidade do entorno e de áreas a montante para reposição do lençol e afloramento da água. Recomenda-se nestas áreas os seguintes dispositivos (Tab.04):

\section{Tab.04}

DISPOSITIVOS DE DRENAGEM EM ÁREAS DE NASCENTES

\begin{tabular}{|l|l|}
\hline Nas edificações & Nas áreas livres e sistema viário \\
\hline & $\begin{array}{l}\text { - Canteiro pluvial sem infiltração } \\
\text { - Bovaleta }\end{array}$ \\
- Teto verde & - Lago pluvial \\
- Canteiro pluvial sem infiltração & - Alagado \\
- Cisterna & - Pavimento drenante \\
& - Córrego reabilitado \\
& - Parque linear \\
\hline
\end{tabular}

Um possível cenário futuro para a Bacia Hidrográfica do Córrego Mandaquí
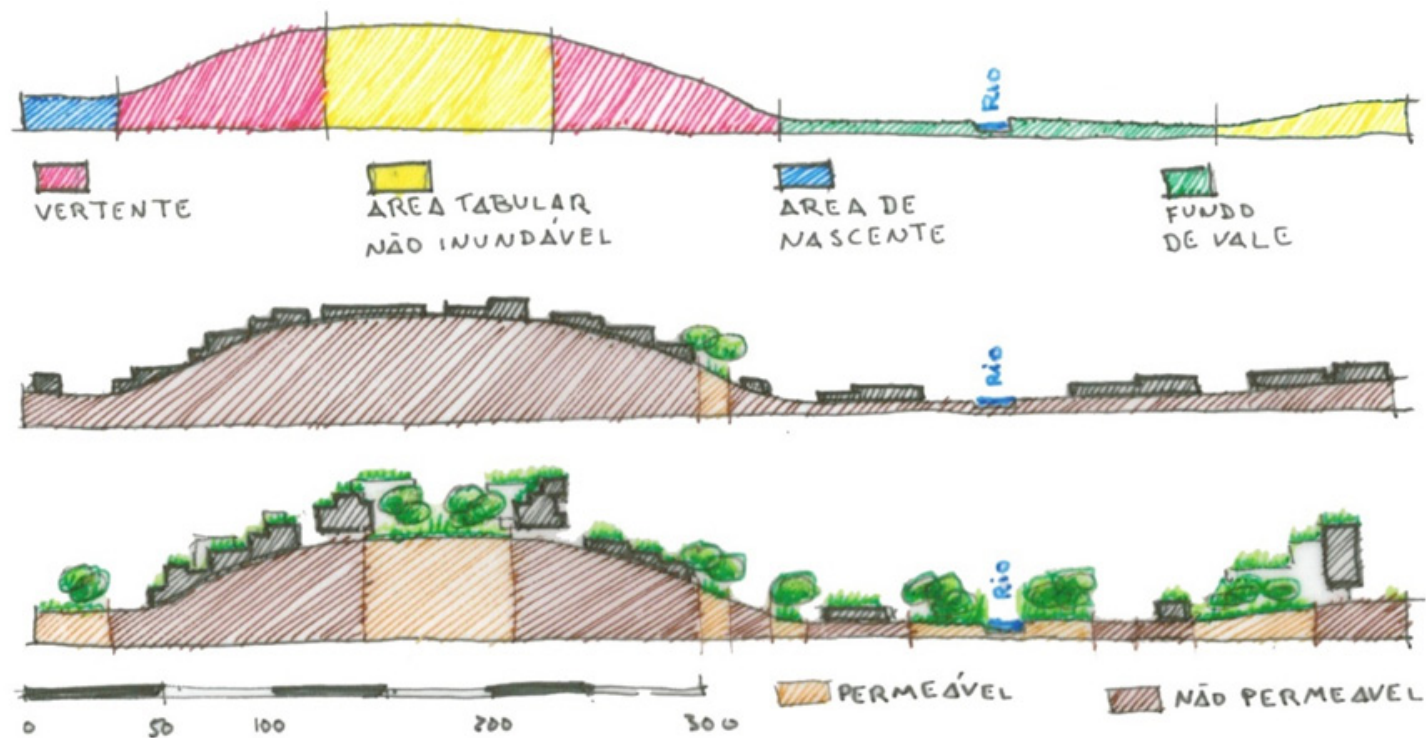

Figura 14 - Compartimentação de relevo e potencial de tranformação 
O caminhar por estas áreas revela uma diversidade de situações. Próximo à Avenida Engenheiro Caetano Álvares é evidente o impacto ambiental do tráfego pesado. Do lado Leste do córrego, há grandes terrenos, estacionamentos, galpões industriais e oficinas de serviços variados. Mais afastado do córrego o uso vai mudando para comércio e serviços com algumas residências remanescentes. Do lado Oeste predomina mais comércio e serviços, muitos em imóveis que já foram residenciais. As residências remanescentes parecem resistir. Nas áreas da várzea a habitação demonstra ter perdido a qualidade ambiental de outras épocas e apresentam maior estado de deterioração e desvalorização. Lá a arborização é quase nula, as calçadas são estreitas o que torna o caminhar penoso.

A qualidade ambiental melhora gradativamente em ambos os lados na medida que 0 pedestre se afasta da avenida. Ainda que as calçadas sejam inadequadas, a diminuição do tráfego traz maior sensação de segurança. Do lado Leste quando atravessamos a avenida José de Brito Feitas, atingimos uma área tabular onde encontramos ruas residenciais mais tranquilas e silenciosas, com algumas árvores de pequeno porte e eventualmente um raro jardim particular.

Do lado Oeste, no topo do morro, protegido por ruas sinuosas, o ambiente contrasta com o resto da área. Com arborização bem mais presente, ainda que longe do ideal, a altitude parece isolar o lugar da cidade lá embaixo. O padrão das casas é mais alto, muitas têm ainda grades baixas com pequenos jardins frontais, guardando um pouco ares de interior.

Já nas encostas do morro a situação dos imóveis não se distingue muito do fundo do vale, ainda que o tráfego seja menor. De modo geral as casas não têm quintal permeável e quando não ocupados totalmente por construções secundárias, os terrenos estão pavimentados. A única área verde da encosta, no entanto, é onde se concentra as árvores de grande porte. É um grande terreno da prefeitura que abriga uma creche e um centro de convivência para crianças e adolescentes.

$\mathrm{Na}$ imagem a seguir (fig.15) apresentamos um cenário futuro, ilustrando a transformação inicial da bacia a partir da implementação do parque linear e dos preceitos acima descritos.

A avenida é afastada do curso d'água e transposta para a face Leste do parque. Cal- 
çadões equipados com ciclovias se estendem dos dois lados. À esquerda da imagem, na face oeste do córrego, vemos o parque na foz do afluente, com lagoas e alagados. Enquanto trata as águas o parque recebe a população para lazer e educação ambiental. Podemos ver o deck elevado sinuoso entre os corpos d'água e um centro de informações ambientais. É um pequeno santuário ecológico às margens do Córrego Mandaquí.

Na mesma face, junto ao parque, os edifícios mais baixos devem concentrar funções institucionais, como escola, creche, centro cultural, esportes, etc.

Nas áreas adjacentes ao parque linear configura-se o desenvolvimento das novas quadras ecológicas. Não mais torres em condomínios fechados, a habitação se abre para a cidade em espaços de uso múltiplo com térreo público e lugares verdes protegidos do tráfego.

As coberturas verdes criam uma continuidade de superfície com o parque, mesclando construção e paisagem. $O$ escalonamento privilegia a vista do parque criando segurança e caminhos para a biodiversidade.

No topo do morro percebemos que parte do casario foi conservada. Junto aos novos edifícios residenciais poderá tanto preservar seu uso habitacional como abrigar comércio, serviços, bares e restaurantes. Atividades noturnas que lá podem ocorrer trarão vida e segurança ao bairro 24 horas por dia. Todas as edificações, novas e antigas, compartilham de novos espaços verdes e elevada qualidade ambiental. 


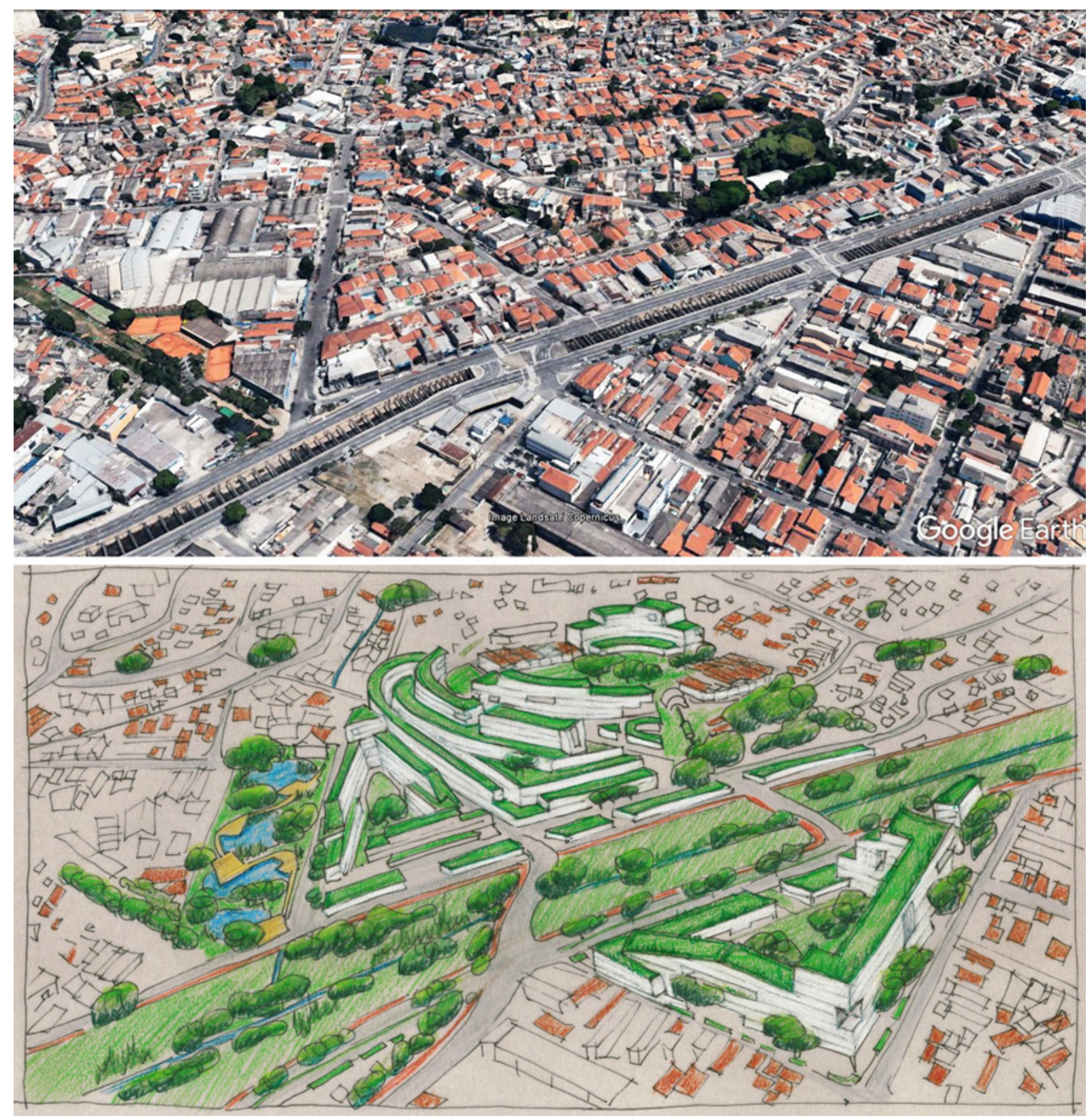

Figura 15 - Tranformações às margens do Córrego Mandaquí

\section{Algumas considerações relevantes:}

\section{Formação de uma cultura local}

Na transformação da cidade, a aplicação de conhecimento técnico junto ao uso de mão de obra local não só gera emprego como pode fomentar o surgimento de uma cultura de construção sustentável. Se academia e construção civil se unem, os can- 
teiros de obra podem se transformar em laboratórios de desenvolvimento de novas tecnologias, associados a escolas de formação de mão de obra especializada. Para que isso se viabilize seria de grande valor a criação de um Programa Municipal para Construção Sustentável.

Através deste programa a bacia hidrográfica, e não o bairro, deve possuir um Plano Diretor. Isto para que o recorte territorial administrativo coincida com a hidrográfia, facilitando a gestão da bacia. Este programa deve conter uma legislação rigorosa baseada em critérios de qualificação socioambiental.

Subsídios e estímulos devem atrair a adesão da iniciativa privada, mudando o paradigma da indústria da construção civil. Com a participação das universidades com assistência técnica e pesquisa de ponta, toda obra deve estar aberta a visitações programadas, servindo de laboratório e "sala de aula" para universidades e escolas técnicas, contribuindo na geração de conhecimento e tecnologia, assim como na formação de profissionais altamente qualificados. As exposições dos projetos, palestras e debates sobre sustentabilidade e construção sustentável, energias renováveis, e outros assuntos pertinentes a um bairro ecológico, devem envolver escolas e toda a comunidade, ampliando o alcance desta cultura à população em geral. Cria-se assim as bases para o desenvolvimento de uma cultura ambiental, modificando radicalmente o olhar da população sobre as qualidades ambientais da cidade.

\section{Habitação solidária e integração social}

As novas quadras residenciais ecológicas, nas bordas da Infraestrutura Verde, devem cumprir o papel de integração social. Se este objetivo não for estabelecido desde o princípio, o resultado não será ecológico. Sem este cuidado, toda melhoria irá, como de costume, ser apropriada pela população de maior renda através dos processos de gentrificação gerados pela especulação imobiliária. Ou seja, sem o cumprimento de função social haverá mais impacto sócio ambiental, com mais expansão horizontal da cidade nas periferias, sobre a zona rural e sobre áreas de proteção ambiental.

Devem ser criadas, para além das ZEIS (Zonas Especiais de Interesse Social) outras políticas para distribuir igualitariamente a cidade, como as Cotas de Solidariedade, já previstas no Plano Diretor do município, que integram no mesmo espaço urbano diferentes grupos sociais. Uma ZEIS já pressupõe segregação porque se destina a 
uma classe social especifica. A habitação solidária, aquela que tem como princípio a reserva de cotas sociais, pode dissolver barreiras entre classes, ainda que seja um processo lento e cheio de desafios.

Só assim conseguiremos a diversidade sociocultural necessária à resiliência. As quadras requalificadas devem adotar as Cotas de Solidariedade. Os $10 \%$ previstos no Plano Diretor Estratégico de São Paulo parecem mais adequado aos obscuros acordos entre poder público e iniciativa privada. Temos que ser ousados e propor um mínimo de $30 \%$ das unidades habitacionais à população de menor renda, não sem garantir educação, saúde e emprego no local. Toda a população removida na restruturação das quadras deve ter prioridade na aquisição e escolha das novas unidades, sem ônus, desde que compatíveis em área às suas antigas residências. Em hipótese alguma pode haver redução na qualidade de vida de alguma família.

Para facilitar o processo de dissolução de barreias sócio culturais a integração social deve extrapolar a questão da moradia para o âmbito da educação e cultura. Para isso devem ser criadas as condições de convívio harmonioso entre crianças e adolescentes de diferentes classes sociais. A escola é o lugar ideal para isso, tanto a pública como a particular, mas programas educacionais avançados são necessários. Como as escolas particulares poderão reservar bolsas às crianças das famílias de menor renda, subsidiadas ou não pelo Estado, é outro estudo a ser desenvolvido. Certamente a requalificação da escola pública, de um modo a torna-la tão boa ou melhor que o ensino privado, é uma condição ideal para esta integração. Quando as crianças e jovens de diferentes níveis de renda crescerem juntas, no convívio diário poderão interagir, criar laços de amizade, superar preconceitos e descobrir a igualdade na diversidade.

Uma rede social diversificada cria capital social democraticamente distribuído, o que significa maiores possibilidades futuras para contatos sociais e profissionais, principalmente para os jovens de famílias de menor renda.

Um projeto urbano ecológico eficiente não trata exclusivamente das áreas livres e edificadas. Ele tem que construir capital natural e social. Edifícios e paisagem são as formas que devem propiciar os bons fluxos, integrados e harmonizados. Tomando o ser humano como uma metáfora para a cidade, as formas construídas e seus espaços abertos são o corpo, os fluxos sociais e naturais são o sangue, a linfa, o alimento, os hormônios, os impulsos nervosos. Um corpo sem fluxo está doente. O fluxo harmonioso dos processos sociais, assim como o dos naturais, é a garantia de um ecossistema urbano sadio e resiliente. 


\section{BIBLIOGRAFIA}

BENEDICT, Mark A.; MCMAHON, Edward T. Green Infraestructure - Linking landscapes and communities. Washington: Island Press, 2006.

BONZI, Ramón Stock. Andar sobre Água Preta: a aplicação da Infraestrutura Verde em áreas densamente urbanizadas.

FRANCO, Maria Assunção Ribeiro. Planejamento ambiental para a cidade sustentável. São Paulo: Annablume,FAPESP, 2001.

GEHL, Jan, Cities for people. Washington DC: Island Press, 2010.

GUNDERSON, Lance H; ALLEN Craig R.; HOLLING, C. S.. Foundations of ecological resilience.

GUNDERSON, Lance H.; HOLLING, C.S. Panarchy, understanding transformations in human and natural systems. Washington: Island press, 2002.

HASS, Tigran (editor). Sustainable Urbanism and Beyond. Nova lorque: Rizzoli, 2012

HILLMAN, James. Cidade e alma. São Paulo: Studio Nobel, 1993

HOUGH, Michael. Cities and natural process. London: Routledge, 1995.

KATZ,P. (org). The new urbanism - Toward an architecture of community. New York: Mc Graw-Jill, 1994.

LOTUFO, José Otávio. Oikos: Reintegrando natureza e civilização. Em, Revista LABVERDE n. 02. São Paulo: FAU-USP, 2011.

LOTUFO, José Otávio. Projeto Sustentável - Resiliência Urbana para o bairro da Pompéia. Tese de Doutorado, FAU-USP, 2016.

MOSTAFAVI, Mohsen ; DOHERTY, Gereth. Ecological urbanism. Baden: Lars Müller, 2010. 
ORBELLE, Oscar; YANNAS, Simos. Em Busca de uma Arquitetura Sustentável para os Trópicos. Rio de Janeiro: Revan, 2003

PEVSNER, Nikolaus. Visual planning and the picturesque. Los Angeles: Getty, 2010

PICKETT, S.T.A.; CADENASSO, M.L.; MCGRATH, Brian. Resilience in ecology and urban design - Linking theory and practice for sustainable cities. New York/London: Springer, 2013.

SÃO PAULO. Câmara Municipal. Lei 16.050/14, Plano Diretor Estratégico. São Paulo: Câmara Municipal, 2014

SCHUTZER, José Guilherme. Cidade e meio ambiente - A apropriação do relevo no desenho ambiental urbano. São Paulo: Edusp, 2012.

WALDHEIN, Charles (org.). The landscape urbanism reader. New York: Princeton Architectural Press, 2006.

YEANG, Ken. Proyectar con la naturaleza. Barcelona: GG, 2007. 